\title{
NINE NEW SPECIES OF BEGONIA (BEGONIACEAE) FROM SOUTH AND WEST SULA WESI, INDONESIA
}

\author{
D. C. Thomas ${ }^{1}$, W. H. Ardi ${ }^{2} \&$ M. Hughes ${ }^{3}$
}

Nine new species of Begonia (Begoniaceae), Begonia comestibilis D.C.Thomas \& Ardi, B. insueta D.C.Thomas \& Ardi, B. lasioura D.C.Thomas \& Ardi, B. nobmanniae D.C.Thomas \& Ardi, B. prionota D.C.Thomas \& Ardi, B. rantemarioensis D.C.Thomas \& Ardi, B. sanguineopilosa D.C.Thomas \& Ardi, B. torajana D.C.Thomas \& Ardi and B. vermeulenii D.C.Thomas, are described from South and West Sulawesi, Indonesia. All belong to Begonia section Petermannia. Proposed conservation categories for these species are Vulnerable (VU) for Begonia comestibilis, B. nobmanniae, B. prionota, B. sanguineopilosa and B. vermeulenii; Least Concern (LC) for B. lasioura, B. rantemarioensis and B. torajana; and Data Deficient (DD) for B. insueta. An identification key to Begonia in South and West Sulawesi (Sulawesi Selatan and Sulawesi Barat) is provided.

Keywords. Begonia, new species, Sulawesi.

\section{INTRODUCTION}

Numerous species of the mega-diverse genus Begonia L. (c.1500 spp.; Hughes, 2008) have been brought to light by recent expeditions to the Indonesian island of Sulawesi, raising the number of known Sulawesi Begonia species from 23 in the year 2005 to 42 to date (after considering the synonymy of species in the Begonia rieckei Warb. and B. aptera Blume complexes; see the checklist in Thomas et al., 2009a, and recent additions to the Sulawesi Begonia flora by Girmansyah et al., 2009; Thomas et al., 2009b; this study). This recent high discovery rate of new Sulawesi Begonia species reflects the degree of past underexploration of Sulawesi, as illustrated by the island having the lowest density of botanical collections of all the large islands in Indonesia (Cannon et al., 2007).

Nine species of Begonia are newly described below. Seven of these were collected on an expedition to South and West Sulawesi in 2009. Descriptions of these species are based on measurements of both herbarium material and living plants in the field.

\footnotetext{
${ }^{1}$ University of Hong Kong, School of Biological Sciences, Pok Fu Lam Road, Hong Kong. E-mail: dthomas@hku.hk

${ }^{2}$ Bogor Botanic Gardens, Jl. Ir. H. Juanda No. 13, Bogor 16003, Indonesia. E-mail: wisnu.handoyo. ardi@lipi.go.id

${ }^{3}$ Royal Botanic Garden Edinburgh, 20A Inverleith Row, Edinburgh EH3 5LR, Scotland, UK. E-mail: m.hughes@rbge.ac.uk
} 
One species, Begonia vermeulenii, is described from herbarium material and from living plants cultivated at Singapore Botanic Garden and the Royal Botanic Garden Edinburgh. The description of another species, Begonia insueta, is based solely on herbarium material. Like the vast majority of Sulawesi Begonia species all of the newly described species belong to Begonia section Petermannia (Klotzsch) A.DC. In common with most members of this section the newly described species exhibit twotepaled male flowers, anthers with unilaterally positioned slits, five-tepaled female flowers (unknown for Begonia insueta), two-flowered female inflorescences or solitary female flowers, three-locular ovaries with axile placentation and bilamellate placentae (unknown for $B$. insueta), and fruits with equal or subequal wings (except for the wingless fruits of $B$. vermeulenii, and the unequal wings of the fruits of B. insueta).

A distribution map including all newly described species is shown in Fig. 1, and diagnostic characters are illustrated in Figs 2-10. All the specimens cited are included in the Southeast Asian Begonia Database (Hughes \& Pullan, 2007), which is accessible online (http://elmer.rbge.org.uk/begonia/).

\section{SPECIES Descriptions}

Begonia comestibilis D.C.Thomas \& Ardi, sp. nov. Sect. Petermannia. Figs 1, 2. A ceteris speciebus Begoniae celebicis combinatione characterum foliorum peltatorum, inflorescentiis masculis valde compressis et alarum fructuum bene evolutarum differt. - Type: Indonesia, Sulawesi, Sulawesi Selatan, Lompobatang Mountains, close to Malino, Katemujotup waterfall, disturbed forest at margin of coffee plantation, $05^{\circ} 16^{\prime} 30.9^{\prime \prime} \mathrm{S}, 119^{\circ} 51^{\prime} 53.7^{\prime \prime} \mathrm{E}, 1030 \mathrm{~m}, 11$ iv 2009 , D.C. Thomas \& W.H. Ardi 09-62 (holo E; iso BO, L).

Perennial, monoecious herb with erect stems, to c. $80 \mathrm{~cm}$ tall, glabrous except for a sparse indumentum of microscopic, glandular hairs. Stems branched; internodes c. $4-13 \mathrm{~cm}$ long, reddish. Leaves alternate, usually excentrically peltate, or sometimes both peltate leaves and leaves with basifixed lamina present; stipules caducous, 13 $17 \times 6-12 \mathrm{~mm}$, elliptic to oblong, with an abaxially prominent midrib that projects up to c. $4 \mathrm{~mm}$ at the apex; petioles $4-18 \mathrm{~cm}$ long, reddish; lamina $13-17.3 \times 7.1-$ $10.5 \mathrm{~cm}$, very asymmetric, ovate to elliptic, leaf margin slightly sinuate close to the petiole (excentrically peltate leaves) or base cordate and lobes not overlapping (basifixed laminas), apex acuminate, margin dentate to serrate to bidentate or biserrate, teeth not bristle-pointed, adaxial surface mid green and abaxial surface pale green, coriaceous, primary veins 5-6, actinodromous, secondary veins craspedodromous. Inflorescences: protogynous; female inflorescences 2-flowered, usually positioned one node below the male inflorescences, peduncles c.1-1.5 mm long; male inflorescences usually distal to the female inflorescences, composed of 1-5 cymosesubumbellate partial inflorescences, each with 1-3 strongly compressed monochasia with up to 7 flowers, peduncles 9-38 mm long. Male flowers: pedicels $15-31 \mathrm{~mm}$ long; 


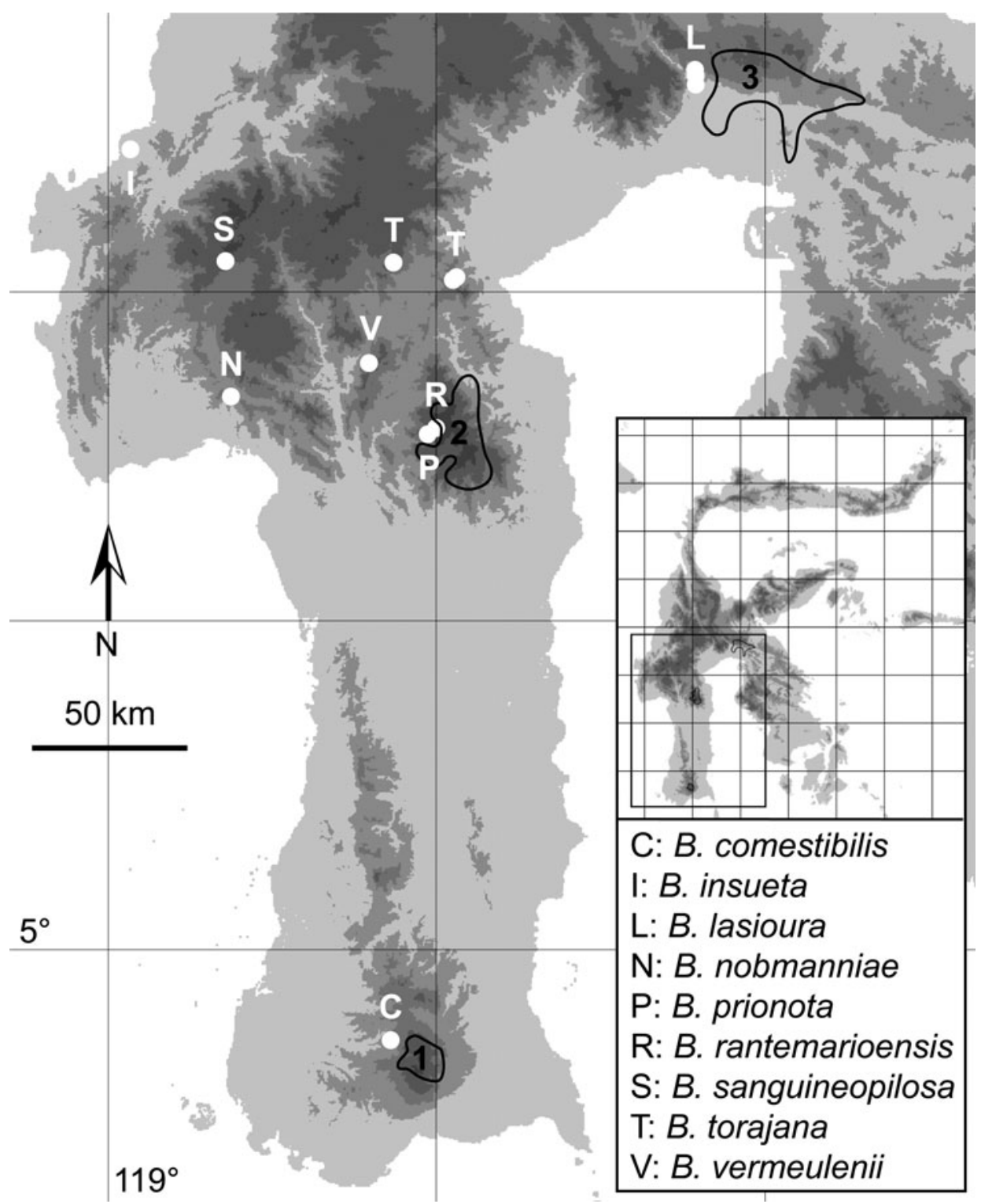

FIG. 1. Distribution map. Collections are indicated by white dots (single dots can indicate multiple collections from the same or nearby localities). The letter directly above or below a white dot indicates the species as shown in the inset. Important protected areas in proximity to the collection sites are indicated by black outlines: 1. Lompobatang Protected Forest (IUCN category VI); 2. Pegunungan Latimojong Protection Forest (IUCN category VI); 3. Pegunungan Feruhumpenai Nature Reserve (IUCN category 1a). Topographical variation is indicated by five shades of grey: 0-500 m (the lightest shade), 500-1000 m, 1000-1500 m, 1500-2000 $\mathrm{m}$, and $>2000 \mathrm{~m}$ (the darkest shade). 

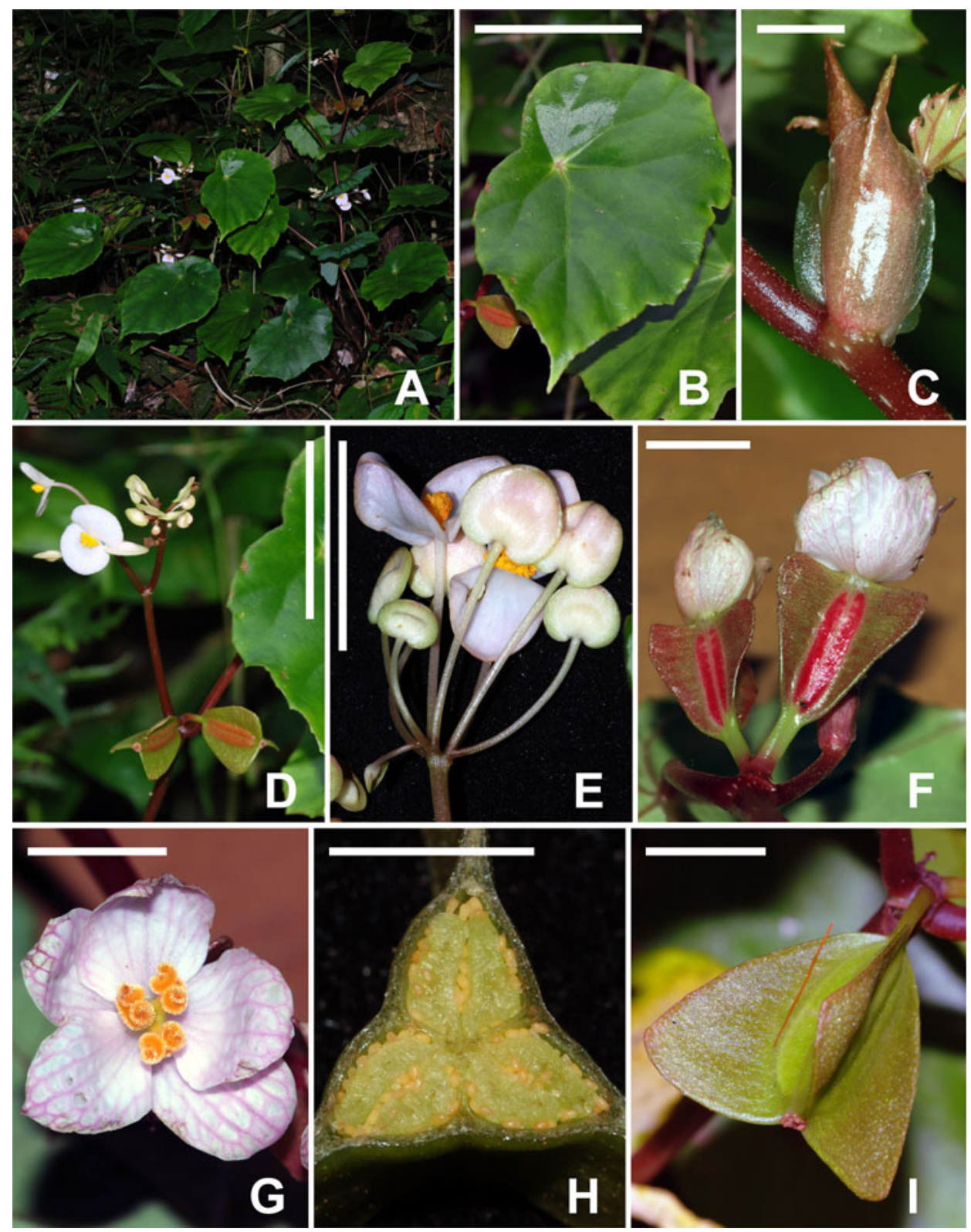

FIG. 2. Begonia comestibilis D.C.Thomas \& Ardi. A, habit; B, leaf; C, stipule; D, inflorescence; E, male cymose-subumbellate partial inflorescence; F, female inflorescence; G, female flower, front view; $\mathrm{H}$, ovary, cross-section, three-locular with axile, bilamellate placentae; I, fruit. A-I: D.C. Thomas \& W.H. Ardi 09-62. Scale bars: $\mathrm{B}=9 \mathrm{~cm} ; \mathrm{C}=5 \mathrm{~mm}$; $\mathrm{D}=5 \mathrm{~cm} ; \mathrm{E}=3 \mathrm{~cm} ; \mathrm{F}=12 \mathrm{~mm} ; \mathrm{G}=15 \mathrm{~mm} ; \mathrm{H}=3 \mathrm{~mm} ; \mathrm{I}=20 \mathrm{~mm}$. 
tepals 2, white, 8-14 $\times 11-17 \mathrm{~mm}$, broadly ovate to suborbicular, base slightly cordate, apex rounded; androecium of c.76-92 stamens, yellow, filaments up to c. $2 \mathrm{~mm}$ long, slightly fused at the very base, anthers c. $0.9-1.5 \mathrm{~mm}$ long, obovate to oblong, dehiscing through unilaterally positioned slits that are $>1 / 2$ as long as the anther. Female flowers: pedicels 6-10 mm long; tepals 5, white with pinkish veins, subequal, 14-18 $\times 8-11 \mathrm{~mm}$, obovate to elliptic; ovary ellipsoid, locules 3 , placentation axile, placentae bilamellate, wings 3 , triangular, subequal, base rounded to cuneate, apex rounded to subtruncate, widest subapically, style basally fused, 3-branched, each stylodium bifurcate in the stigmatic region, stigmatic surface a spirally twisted papillose band, yellow. Fruiting pedicels up to $1 \mathrm{~cm}$ long. Fruits semi-fleshy, ellipsoid, 17-26 $\times$ 6-10 $\mathrm{mm}$ (excluding the wings), indehiscent?, wing shape as for ovary, 11-16 mm wide at the widest point (at the apex); seeds ellipsoidal, c. $0.35-0.4 \mathrm{~mm}$ long, collar cells c. $1 / 2-2 / 3$ of the length of the seed.

Distribution. Indonesia, Sulawesi, South Sulawesi (Sulawesi Selatan), Lompobatang Mountains, close to Malino (Fig. 1).

Habitat. This is a rainforest floor species, observed on a steep slope at c.1020-1040 m above sea level.

Proposed IUCN conservation category. Vulnerable (VU D2). The Lompobatang massif is densely populated, and the majority of forest below $1700 \mathrm{~m}$ is heavily disturbed or has been converted by logging and land clearance for settlements and agriculture. This also holds true for the area surrounding the forest patch in which Begonia comestibilis was collected. The known distribution of this species falls outside the Lompobatang Protected Forest (IUCN category VI). Although all available Begonia specimens from A, B, BM, BO, CEB, E, K, L, SING and WAG have been consulted, only two collections are known. Hence it must be assumed, at least until more intensive collecting on Sulawesi reveals otherwise, that this species has a very restricted extent of occurrence. Begonia comestibilis grows abundantly at the type locality, but because of the restricted distribution the population is likely to be 'prone to the effects of human activities or stochastic events within a very short time period in an uncertain future' (IUCN, 2001). Given the pressures on the forests in this region, and the direct threat to the only known population by human activity (extensive coffee plantations, rice agriculture, human settlements), this species must be considered vulnerable. Close monitoring of the population might indicate an even higher threat category.

Additional specimen examined. SulawesI. South Sulawesi: Malino, 10 x 1931, A. Rant 421 (BO).

The specific epithet is derived from comestibilis (Latin - edible). The leaves of Begonia comestibilis, which is called Indokaciling in the Malay dialect of the local people, are locally used as a vegetable and either eaten raw for their sour and refreshing taste or as an ingredient for a sour sauce used for chicken dishes. Begonia 
comestibilis belongs to a group of Sulawesi species which show either a fleshy, relatively thick pericarp and reduced wings (Begonia guttapila, B. vermeulenii, $B$. rieckei) or a semi-fleshy pericarp, often thick placenta lamellae and well-developed wings (B. comestibilis, B. sanguineopilosa, B. torajana). Numerous fruits and ovaries of Begonia comestibilis at various ontogenetic stages were observed in the field in April 2009, and none of the fruits showed any signs of dehiscence. Further observations later in the season are needed to confirm whether these fruits are indehiscent or whether they dehisce in the usual mode with lines of dehiscence along the bases of the wings.

Peltate species are rare in the large Begonia section Petermannia, and only one peltate-leaved species, Begonia varipeltata D.C.Thomas, was previously known from Sulawesi (Thomas \& Hughes, 2008). Begonia comestibilis differs from B. varipeltata by numerous vegetative and generative characters such as the strongly compressed subumbellate male inflorescences, the very shortly pedunculate female inflorescences and the semi-fleshy fruits. It differs from the only other peltate species on Sulawesi, Begonia vermeulenii, in having winged fruit and leaves which are more shallowly dentate or serrate. With regard to the generative characters, Begonia comestibilis is similar to B. guttapila, which also exhibits compressed cymose-subumbellate male inflorescences, very short peduncles of the female inflorescences and fleshy fruits. However, the peltate, slightly succulent and coriaceous leaves and the longer pedicels of the female flowers of Begonia comestibilis make it easy to differentiate this species from B. guttapila.

Begonia insueta D.C.Thomas \& Ardi, sp. nov. Sect. Petermannia. Figs 1, 3.

Species distinctissima. A ceteris speciebus celebicis foliis palmatim compositis, pedunculis inflorescentiarum feminearum brevibus, pedicellis florum feminearum longis et alis fructuum inaequalibus differt. - Type: Indonesia, Sulawesi, Sulawesi Barat, Kab. Mamuju, Kec. Kaluku, Kp. Popangatalu, Bukit Tabase, c.100 m, 8 ii 1993, J.J. Afriastini 2085 (holo BO).

Perennial, monoecious herb, with erect stems, to c.100 cm tall, with a moderately dense to dense indumentum of multicellular, simple trichomes up to c. $0.6 \mathrm{~mm}$ long and a sparse indumentum of microscopic, glandular trichomes on all above-ground vegetative parts. Stems branched; internodes c.3.9-7.2 cm long. Leaves alternate; stipules caducous, 6-11 $\times 2.5-5 \mathrm{~mm}$, ovate, with an abaxially prominent midrib that projects c.2-4 $\mathrm{mm}$ at the apex; petioles c. $4-10 \mathrm{~cm}$ long; lamina basifixed, palmately compound with 5-7 leaflets, each leaflet 2.9-9.5 $\times 1.6-2.5 \mathrm{~cm}$, asymmetric, ovate or ellipsoid, base cuneate to concavo-convex, apex acuminate, margin irregularly serrate to biserrate, teeth bristle-pointed, primary veins 5-7, actinodromous, secondary veins craspedodromous. Inflorescences: female inflorescences 2-flowered, solitary, peduncles c.0.5-1 mm long; male inflorescences solitary, partial inflorescences monochasial with short but well-developed axes, each monochasium with c.5-7 flowers. Male flowers: pedicels c.2-3 mm long; tepals 2, pink, 4-5 × 3-4 mm, broadly 


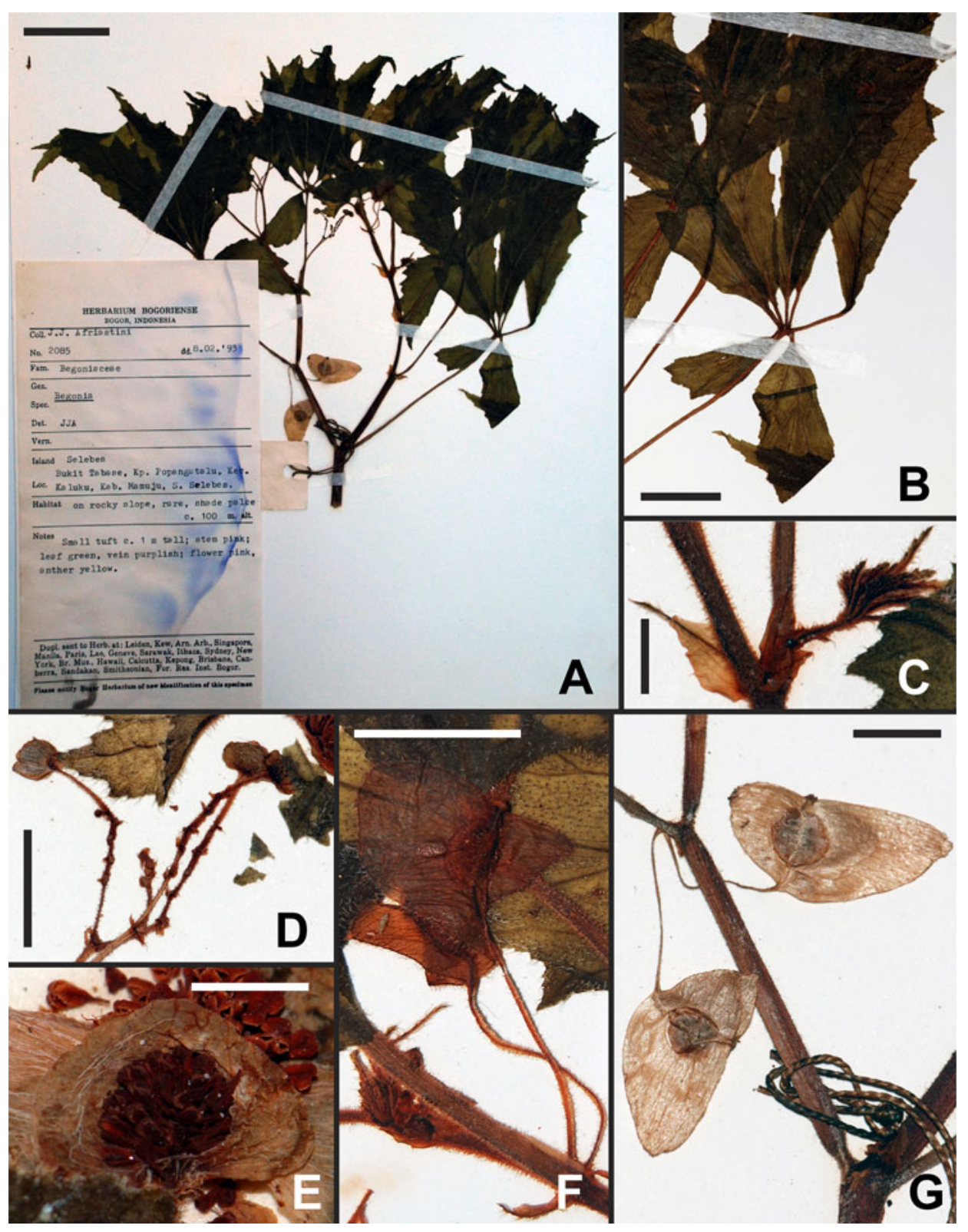

FIG. 3. Begonia insueta D.C.Thomas \& Ardi. A, holotype; B, leaf; C, stipule and ontogenetically young leaf; D, male partial inflorescences; $E$, male flower; $F$, inflorescence; $G$, infructescence. A-G: J.J. Afriastini 2085. Scale bars: A $=5 \mathrm{~cm} ; \mathrm{B}=2 \mathrm{~cm} ; \mathrm{C}=5 \mathrm{~mm} ; \mathrm{D}=1 \mathrm{~cm} ; \mathrm{E}=2 \mathrm{~mm}$; $\mathrm{F}, \mathrm{G}=10 \mathrm{~mm}$.

ovate to suborbicular, base cordate, apex rounded, abaxially with a sparse indumentum of multicellular hairs; androecium of c.28-42 stamens, yellow, filaments up to c. $0.8 \mathrm{~mm}$ long, slightly fused at the base, anthers up to c. $0.6 \mathrm{~mm}$ long, obovate, 
dehiscing through unilaterally positioned slits that are $>1 / 2$ as long as the anther. Female flowers: pedicels 15-19 mm long; tepals unknown; ovary ellipsoid, with a sparse indumentum of microscopic hairs and a sparse indumentum of multicellular hairs, locule number and placentation unknown, wings 3, strongly unequal, triangular, base rounded to cuneate, apex subtruncate to rounded, style unknown. Fruiting pedicels $16-19 \mathrm{~mm}$ long. Fruits subglobose, c.6-7 $\times 5-6 \mathrm{~mm}$ (excluding the wings), sparsely hairy to glabrescent, dehiscent, splitting along the wing attachment, wing shape as for ovary, the largest c.14-16 mm wide at the widest point (subapically), the two smaller c.6-8 $\mathrm{mm}$ wide at the widest point (subapically); seeds ellipsoidal, c. $0.3 \mathrm{~mm}$ long, collar cells c. $1 / 2$ of the length of the seed.

Distribution. Indonesia, Sulawesi, Sulawesi Barat, Kab. Mamuju, Kec. Kaluku, Kp. Popangatalu, Bukit Tabase (Fig. 1).

Habitat. This species was observed growing on a rocky slope, in full shade, at c. $100 \mathrm{~m}$ above sea level.

Proposed IUCN conservation category. Data Deficient (DD). The species is only known from one collection. The locality could not be georeferenced with certainty, and the population has not been observed in the field.

The species epithet insueta is derived from insuetus (Latin - unusual). It refers to the unusual morphological characters exhibited by this species. Begonia insueta can be placed in Begonia section Petermannia based on the two-flowered female inflorescences and the anthers dehiscing through unilaterally positioned slits (Fig. 3E, G). However, it exhibits several characters which are rare in this large and morphologically diverse section including unequally sized fruit wings and palmately compound leaves, which have only been described from three other species in the Malesian region: Begonia oligandra Merr. \& L.M.Perry, B. polilloensis Tebbitt and Begonia rachmatii Tebbitt (see key in Tebbitt, 2005b). The Sulawesi Begonia rachmatii is morphologically dissimilar to $B$. insueta and can be differentiated by multiple characters including the solitary female flowers, very short pedicels of the female flowers (c.1 mm long), and wings which are subequal in size (see key below). The distinctly unequal wings of the fruits in Begonia insueta are highly uncommon in Begonia section Petermannia. However, strongly unequal fruit wings can also be found in the New Guinean species Begonia oligandra, which also exhibits palmately compound leaves. This species has tentatively been assigned to Begonia section Diploclinium (Lindl.) A.DC. by Doorenbos et al. (1998), but the lack of specialised underground organs like rhizomes or tubers indicates that its affinities are with New Guinean species in Begonia section Petermannia. However, the well-developed stalks and the serrate margins of the leaflets of Begonia insueta allow easy differentiation of this species from $B$. oligandra, which exhibits pinnatifid to bipinnatifid leaflets with extremely short stalks. The leaf morphology of the Philippine endemic Begonia polilloensis is similar to $B$. insueta, but the leaflets of $B$. polilloensis are not distinctly stalked, the female flowers are solitary, and the fruit wings are subequal in size. 


\section{Begonia lasioura D.C.Thomas \& Ardi, sp. nov. Sect. Petermannia. Figs 1, 4.}

Begoniae didymae D.C.Thomas \& Ardi in indumento partium vegetativarum et generativarum bene evoluto, stipulis cum appendicula apicali longa pilosaque et fructus forma generali superficie similis sed a qua foliis distincte majoribus $(8-21.5 \times$ $6-12 \mathrm{~cm}$ nec $4.2-6.7 \times 2.6-4.7 \mathrm{~cm}$ ) et floribus in inflorescentiis masculis magis numerosis (usque ad c.15 nec 2[-3]) differt. - Type: Indonesia, Sulawesi, Sulawesi

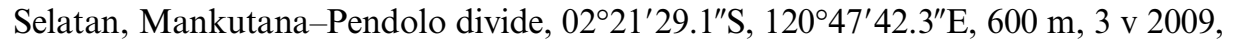
D.C. Thomas \& W.H. Ardi 09-110 (holo E; iso BO, L).

Perennial, monoecious herb, stems erect, to c. $60 \mathrm{~cm}$ tall, with a moderately dense to dense indumentum of multicellular, simple trichomes up to c.1.8 $\mathrm{mm}$ long and a sparse indumentum of microscopic, glandular trichomes on all above-ground vegetative parts. Stems branched; internodes c.2-17.5 cm long, reddish. Leaves alternate; stipules persistent, 16-26 × 6-10 mm, elliptic to oblong, with an abaxially prominent midrib projecting up to $12 \mathrm{~mm}$ at the apex; petioles $4-18 \mathrm{~cm}$ long, reddish; lamina 8-21.5 ×6-12 cm, very asymmetric, ovate to elliptic, base cordate and lobes not or sometimes slightly overlapping, apex long acuminate, margin serrate, teeth long bristle-pointed, adaxial surface dark green and abaxial surface pale green, primary veins 4-5, actinodromous, secondary veins craspedodromous. Inflorescences: protogynous; female inflorescences (1-)2-flowered, positioned one node below the male inflorescences or solitary, peduncles c.1-7 mm long; male inflorescences composed of 24 cymose-subumbellate partial inflorescences, each with (1-)2 compressed monochasia with 2-6 flowers, peduncles 13-26 mm long. Male flowers: pedicels 10-16 mm long; tepals 2 , greenish when young, whitish or whitish tinged with pink at maturity, 7-11 $\times$ $8-11 \mathrm{~mm}$, broadly ovate to suborbicular, base slightly cordate, apex rounded, abaxially with a sparse to moderately dense indumentum of multicellular, reddish hairs and microscopic glandular hairs; androecium of c.37-47 stamens, yellow, filaments up to c. $1 \mathrm{~mm}$ long, slightly fused at the very base, anthers up to c. $1 \mathrm{~mm}$ long, obovate, dehiscing through unilaterally positioned slits that are c.1/2 as long as the anthers. Female flowers: pedicels 1-2 mm long; tepals 5, whitish tinged with pink, unequal, the smaller 10-11 $\times 4-5 \mathrm{~mm}$, ovate to elliptic, the larger 10-12 $\times 7-9 \mathrm{~mm}$, ovate to elliptic, margin and abaxial surface with a sparse indumentum of microscopic glandular hairs and multicellular, reddish hairs; ovary ellipsoid, with a sparse indumentum of microscopic hairs and a moderately dense indumentum of reddish multicellular hairs, locules 3, placentation axile, placentae bilamellate, wings 3, triangular, subequal, base rounded, apex truncate, style basally fused, 3-branched, each stylodium bifurcate in the stigmatic region, stigmatic surface a spirally twisted papillose band, orange. Fruiting pedicels 1-4 mm long. Fruits ellipsoid, 12-14 $\times$ 4-6 $\mathrm{mm}$ (excluding the wings), moderately densely hairy to glabrescent, dehiscent, splitting along the wing attachment, wing shape as for ovary, 6-8 $\mathrm{mm}$ wide at the widest point (at the apex); seeds ellipsoidal, c. $0.3 \mathrm{~mm}$ long, collar cells c. $1 / 2-2 / 3$ of the length of the seed.

Distribution. Indonesia, Sulawesi, Sulawesi Selatan, Mankutana-Pendolo divide (Fig. 1). 

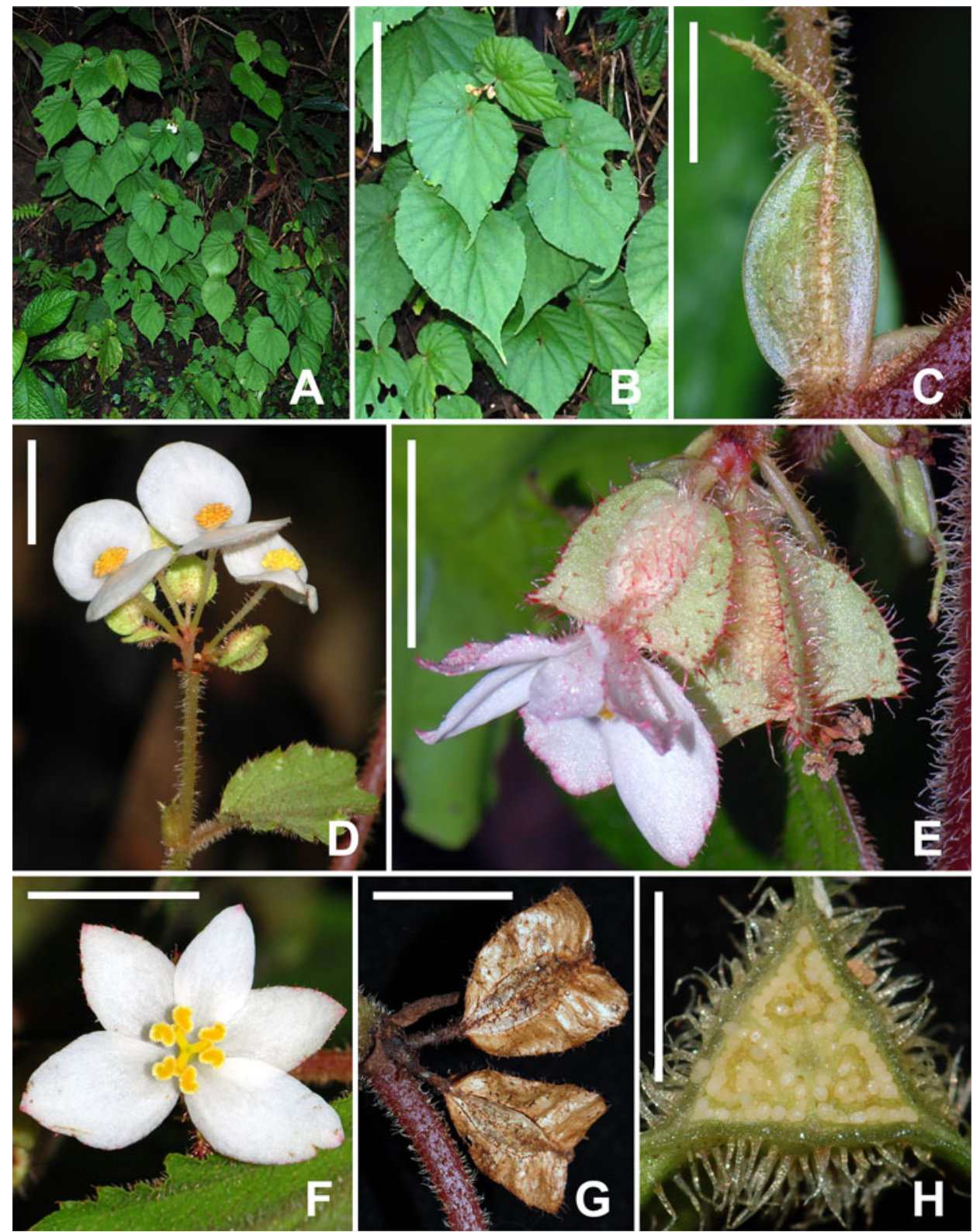

FIG. 4. Begonia lasioura D.C.Thomas \& Ardi. A, habit; B, habit; C, stipule; D, male cymosesubumbellate inflorescence; E, female inflorescence; F, female flower, front view; G, infructescence; $\mathrm{H}$, ovary, cross-section, three-locular with axile, bilamellate placentae. A-H: D.C. Thomas \& W.H. Ardi 09-110. Scale bars: $\mathrm{B}=10 \mathrm{~cm} ; \mathrm{C}=8 \mathrm{~mm}$; D-F $=10 \mathrm{~mm}$; $\mathrm{G}=12 \mathrm{~mm} ; \mathrm{H}=3 \mathrm{~mm}$. 
Habitat. This species grows lithophytically in full shade on rock walls in primary rainforest between c.500 and $1000 \mathrm{~m}$ above sea level.

Proposed IUCN conservation category. Least Concern (LC). Several subpopulations of Begonia lasioura were observed along the road connecting Mankutana and Pendolo, where the species is locally common. All of the collection sites and observed subpopulations lie in close proximity, but outside the Pegunungan Feruhumpenai Nature Reserve (IUCN category 1a). However, further exploration might reveal that the distribution of this species extends into this protected area. Given the occurrence of extensive stretches of high quality primary forest on the Pendolo-Mankutana divide, an IUCN conservation category of LC seems to be indicated.

Additional specimens examined. Sulawesi. South Sulawesi: Mankutane, Mankutane-Pendolo divide, 4 ii 2004, J.J. Vermeulen 2483 (SING, WAG); ibid., 3 v 2009, D. C. Thomas \& W.H. Ardi 09-114 (BO, E, L); ibid., 3 v 2009, D.C. Thomas \& W.H. Ardi 09-116 (BO, E, L).

The specific epithet is a compound of lasio (Greek - shaggy) and oura (Greek - tail). The specific epithet refers to the apical appendices of the stipules of this species, as well as the long appendiculate apices of the leaves (Fig. 4B, C). Both short apical stipule appendages formed by protruding midribs and apiculate apices of the leaves are common in many species in Begonia section Petermannia. However, the apical stipule appendages of Begonia lasioura are notable as they can comprise up to almost half of the length of the stipules and are distinctly hairy, and the drip-tips of the hairy leaves are more distinct than in most Sulawesi species.

\section{Begonia nobmanniae D.C.Thomas \& Ardi, sp. nov. Sect. Petermannia. Figs 1, 5.}

Begoniae rachmatii Tebbitt architectura inflorescentiae cum pedunculis inflorescentiae partialis femineae brevibus et ramificatione complici reminiscientia est. A hac specie foliis indivisis et fructibus longioribus (14-17 mm longis nec 8-12 mm) differt. - Type: Indonesia, Sulawesi, Sulawesi Barat, Road Polewali to Mamasa, $03^{\circ} 18^{\prime} 51.9^{\prime \prime} \mathrm{S}, 119^{\circ} 22^{\prime} 24.5^{\prime \prime} \mathrm{E}, 879$ m, 7 v 2009, D.C. Thomas \& W.H. Ardi 09-123 (holo $\mathrm{E}$; iso $\mathrm{BO}, \mathrm{L}$ ).

Perennial, monoecious herb, with erect stems, to c. $25 \mathrm{~cm}$ tall, glabrous except for a sparse indumentum of microscopic, glandular trichomes, or sometimes exhibiting a sparse indumentum of multicellular, simple trichomes up to c. $0.5 \mathrm{~mm}$ long on all above-ground vegetative parts. Stems branched; internodes c.2-7 cm long, reddish to brownish. Leaves alternate; stipules caducous, 8-14 $\times 4-7 \mathrm{~mm}$, ovate or oblong, with an abaxially prominent midrib that projects shortly at the apex; petioles $\mathrm{c} .2-4 \mathrm{~cm}$ long, greenish or reddish; lamina 5.5-11 $\times 3-5.5 \mathrm{~cm}$, very asymmetric, ovate, base cordate and lobes not or slightly overlapping, apex acuminate, margin biserrate, teeth not bristle-pointed, adaxial surface dark green and variegated with small white spots, abaxial surface reddish, primary veins 4-5, actinodromous, secondary veins craspedodromous. Inflorescences: protogynous; female inflorescences 2-flowered or female flowers solitary, basal to male inflorescences, peduncles c. $1 \mathrm{~mm}$ long; male 

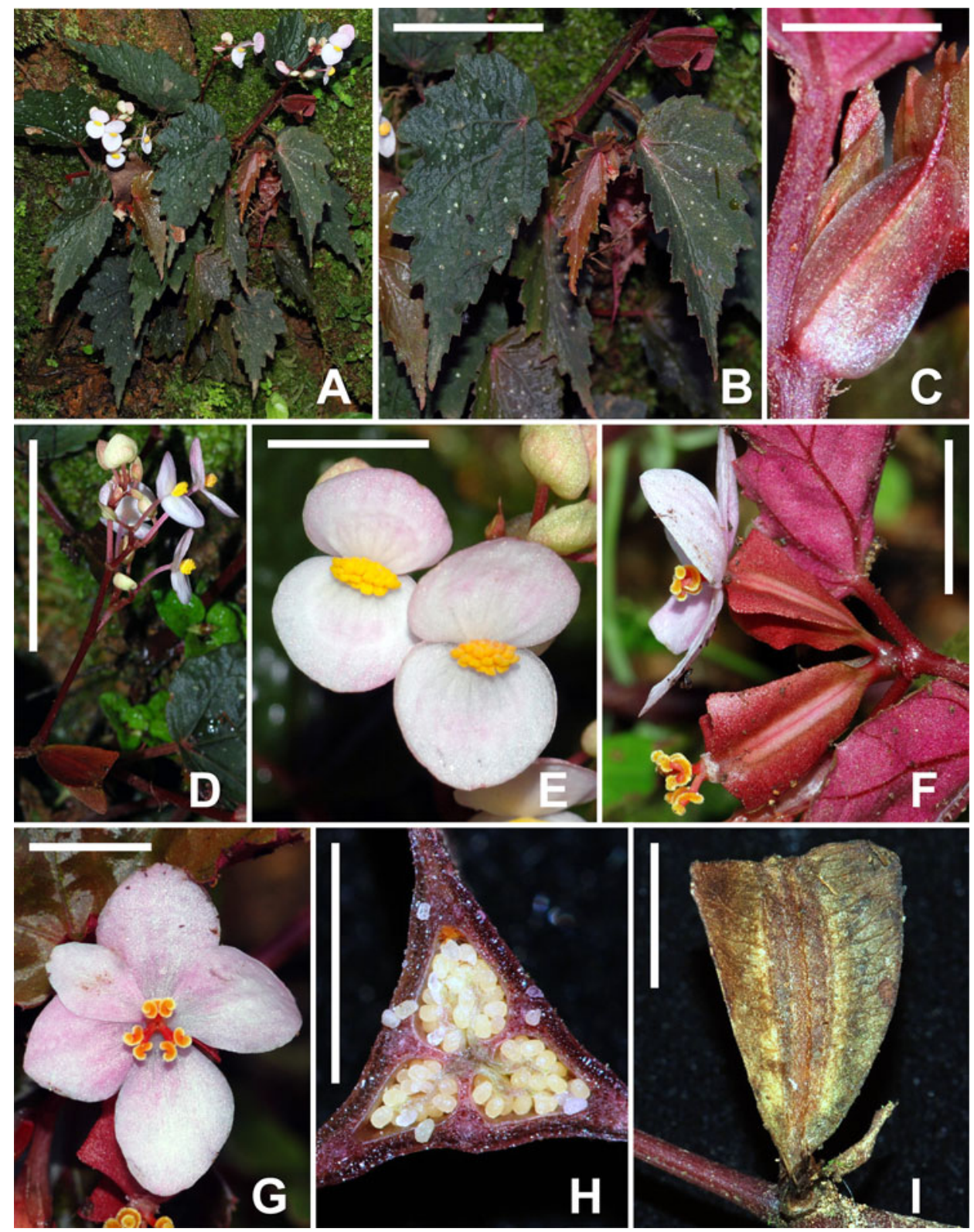

FIG. 5. Begonia nobmanniae D.C.Thomas \& Ardi. A, habit; B, leaves; C, stipule; D, inflorescence; E, male flowers; F, female inflorescence; $G$, female flower, front view; H, ovary, cross-section, three-locular with axile, bilamellate placentae; I, fruit. A-I: D.C. Thomas \& W.H. Ardi 09-123. Scale bars: $\mathrm{B}=4 \mathrm{~cm} ; \mathrm{C}=6 \mathrm{~mm} ; \mathrm{D}=5 \mathrm{~cm} ; \mathrm{E}=12 \mathrm{~mm} ; \mathrm{F}, \mathrm{G}=10 \mathrm{~mm} ; \mathrm{H}=$ $3 \mathrm{~mm}$; I $=8 \mathrm{~mm}$.

inflorescences distal to female inflorescences, superinflorescence usually multiple times branched, the axes separating 2-10 partial inflorescences, each consisting of 
1-2 monochasia, each monochasium with 1-4 flowers. Male flowers: pedicels c.8-21 mm long; tepals 2, white or pink, 7-14 $\times 9-14 \mathrm{~mm}$, broadly ovate to suborbicular, base cordate, apex rounded; androecium of c.30-42 stamens, yellow, filaments up to c. $1.5 \mathrm{~mm}$ long, slightly fused at the base, anthers up to c. $1.1 \mathrm{~mm}$ long, obovate, dehiscing through unilaterally positioned slits that are $>1 / 2$ as long as the anther. Female flowers: pedicels c. $1 \mathrm{~mm}$ long; tepals 5, pinkish, subequal to unequal, 9-13 $\times 5-12 \mathrm{~mm}$, elliptic to obovate; ovary ellipsoid, locules 3, placentation axile, placentae bilamellate, wings 3 , narrowly triangular, subequal, base rounded to cuneate, apex rounded or truncate, widest at the apex or subapically, style basally shortly fused, 3-branched, each stylodium bifurcate in the stigmatic region, stigmatic surface a spirally twisted papillose band, yellow. Fruiting pedicels up to c. $2 \mathrm{~mm}$ long. Fruits ellipsoid, c.14-17 $\times 3.5-4 \mathrm{~mm}$ (excluding the wings), dehiscent, splitting along the wing attachment, wing shape as for ovary, up to $8 \mathrm{~mm}$ wide at the widest point; seeds ellipsoidal, c. $0.3 \mathrm{~mm}$ long, collar cells c. $1 / 2$ of the length of the seed.

Distribution. Indonesia, Sulawesi, Sulawesi Barat, Road Polewali to Mamasa, only known from the type locality (Fig. 1).

Habitat. This species was observed growing lithophytically on an almost vertical rock wall between c.850 and $900 \mathrm{~m}$ above sea level.

Proposed IUCN conservation category. Vulnerable (VU D2). Only a single population has been observed in the field. All available Begonia specimens from A, B, BM, BO, CEB, E, K, L, SING and WAG have been consulted. Hence it must be assumed, at least until more intensive collecting on Sulawesi reveals otherwise, that this species has a very restricted extent of occurrence, which does not fall into any legally protected areas. Moreover, the only known population is adjacent to the Road Polewali-Mamasa, and clearly has been influenced by road construction work. Therefore, it is likely it is 'prone to the effects of human activities or stochastic events within a very short time period in an uncertain future' (IUCN, 2001).

The species is named in honour of the German plant geneticist and Begonia enthusiast Barbara Nobmann, who generously supported an expedition to Sulawesi in 2009.

The inflorescence architecture of Begonia nobmanniae, which is characterised by subsessile, sometimes solitary, female flowers and fruits and the complex branching of the male inflorescence, is similar to the conditions found in B. rachmatii. However, Begonia nobmanniae is not just a simple-leaved variant of $B$. rachmatii, but shows a less delicate growth habit and also differs from it by the larger fruits and tepals, and the more strongly compressed monochasial male partial inflorescences.

\section{Begonia prionota D.C.Thomas \& Ardi, sp. nov. Sect. Petermannia. Figs 1, 6.}

A ceteris speciebus celebicis tepalis florum femineorum irregulariter serratis, alis fructuum serrulatis et superinflorescentia mascula multoties ramosa cum internodiis bene evolutis et inflorescentiis partialibus monochasialibus distinguitur. - Type: Indonesia, Sulawesi, Sulawesi Selatan, Gunung Rantemario, 03²4'59.0”S, 

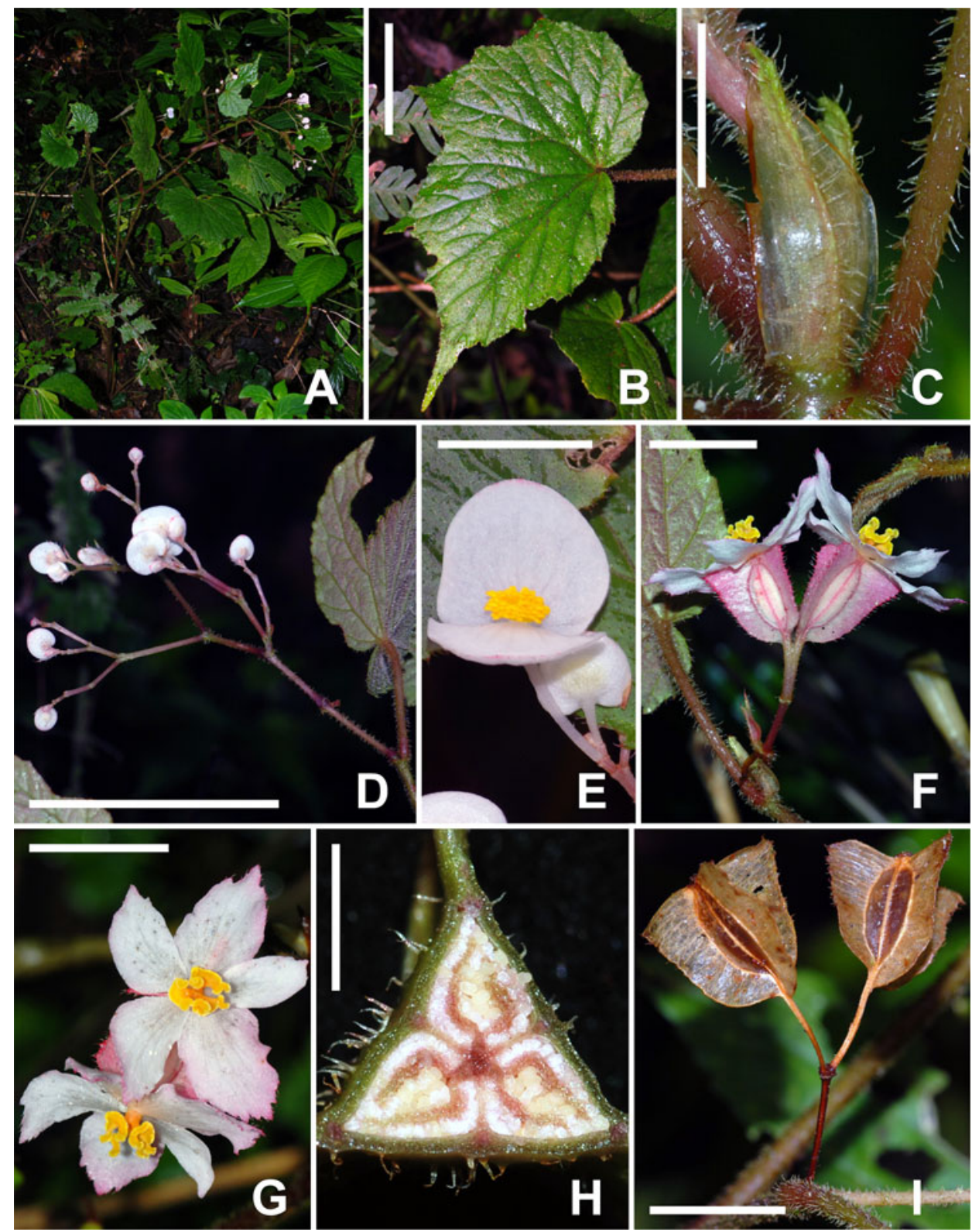

FIG. 6. Begonia prionota D.C.Thomas \& Ardi. A, habit; B, leaf; C, stipule; D, male inflorescence; E, male flower; F, female inflorescence; $G$, female flowers; $H$, ovary, crosssection, three-locular with axile, bilamellate placentae; I, infructescence. A-I: D. C. Thomas \& W.H. Ardi 09-97. Scale bars: $\mathrm{B}=4 \mathrm{~cm} ; \mathrm{C}=6 \mathrm{~mm} ; \mathrm{D}=7 \mathrm{~cm} ; \mathrm{E}=16 \mathrm{~mm} ; \mathrm{F}=14 \mathrm{~mm}$; , $\mathrm{I}=15 \mathrm{~mm} ; \mathrm{H}=3 \mathrm{~mm}$. 
11959'34.7"E, 2175 m, 27 iv 2009, D.C. Thomas \& W.H. Ardi 09-97 (holo E; iso $\mathrm{BO}, \mathrm{L})$.

Perennial, monoecious herb with erect stems, to c. $80 \mathrm{~cm}$ tall, with a moderately dense indumentum of multicellular, simple trichomes up to c. $1.2 \mathrm{~mm}$ long and a sparse indumentum of microscopic, glandular trichomes on all above-ground vegetative parts. Stems branched; internodes c.3-11 cm long, brownish-reddish. Leaves alternate; stipules caducous, 9-15 × 3-9 mm, ovate to oblong, with an abaxially prominent midrib slightly projecting at the apex; petioles $3-10 \mathrm{~cm}$ long, reddish or brownish; lamina 8-15 $\times 4-10 \mathrm{~cm}$, very asymmetric, ovate to elliptic, base cordate and lobes not overlapping, apex acuminate, margin biserrate to shallowly lobed (up to c. $25 \%$ of the lamina width), irregularly scalloped, teeth long bristle-pointed, adaxial surface dark green and abaxial surface pale green, primary veins 5-6, actinodromous, secondary veins craspedodromous. Inflorescences: protogynous; female inflorescences 2-flowered, positioned one node below the male inflorescences or solitary, peduncles c.12-20 mm long; male inflorescences distal to the female inflorescences or solitary, superinflorescence usually multiple times branched, with well-developed axes separating 2-12(-16) monochasial partial inflorescences, each with c.3-8 flowers. Male flowers: pedicels 8-13 mm long; tepals 2, white or pinkish, $10-17 \times 14-16 \mathrm{~mm}$, broadly ovate, base slightly cordate, apex rounded, abaxially with a sparse indumentum of larger multicellular hairs and microscopic glandular hairs; androecium of c.47-59 stamens, yellow, filaments up to c. $2.5 \mathrm{~mm}$ long, slightly fused at the very base, anthers up to c. $1 \mathrm{~mm}$ long, obovate, dehiscing through unilaterally positioned slits that are $>1 / 2$ as long as the anther. Female flowers: pedicels $8-11 \mathrm{~mm}$ long; tepals 5 , white with a pink tinge, unequal, smallest $8-14 \times 5-$ $7 \mathrm{~mm}$, larger $12-16 \times 8-13 \mathrm{~mm}$, elliptic, the margin irregularly serrate from around the middle to the apex, abaxially with a sparse indumentum of microscopic glandular hairs and larger multicellular hairs; ovary ellipsoid, with a sparse indumentum of microscopic hairs and some larger multicellular hairs, locules 3, placentation axile, placentae bilamellate, wings 3 , triangular, subequal, base rounded, apex truncate, the margin irregularly denticulate to serrulate, teeth extended into multicellular hairs up to c. $1 \mathrm{~mm}$ long, style basally fused, 3-branched, each stylodium bifurcate in the stigmatic region, stigmatic surface a spirally twisted papillose band, orange. Fruiting pedicels up to $13 \mathrm{~mm}$ long. Fruits ellipsoid, 14-16 $\times 6-7 \mathrm{~mm}$ (excluding the wings), sparsely to moderately densely hairy, dehiscent, splitting along the wing attachment, wing shape as for ovary, 9-11 mm wide at the widest point (at the apex); seeds ellipsoidal, c. $0.3 \mathrm{~mm}$ long, collar cells c.1/2-2/3 of the length of the seed.

Distribution. Indonesia, Sulawesi, Sulawesi Selatan, Latimojong Mountains, Gunung Rantemario (Fig. 1).

Habitat. This species grows in full shade on steep slopes or lithophytically on rock walls in primary rainforest between c.1300 and $2200 \mathrm{~m}$ above sea level. 
Proposed IUCN conservation category. Vulnerable (VU D2). The distribution of Begonia prionota lies just outside the western border of the Pegunungan Latimojong Protection Forest (IUCN category VI). The collections of this species are from a primary forest pocket along a small stream, where Begonia prionota grows abundantly, but the immediately surrounding area shows moderate to strong anthropogenic disturbance (logging, agriculture, settlements). No other populations of this species could be found in close proximity to the type locality or along a track leading up to the summit of Gunung Rantemario. Moreover, all available Begonia specimens from A, B, BM, BO, CEB, E, K, L, SING and WAG have been consulted. Hence it must be assumed, at least until more intensive collecting on Sulawesi reveals otherwise, that this species has a very restricted range in the Latimojong Mountains.

Additional specimens examined. SulawesI. South Sulawesi: Kab. Enrekang, Kec. Baraka, Eran Batu, 1 ix 1994, D. Girmansyah 50 (BO); ibid., 1 ix 1994, D. Girmansyah 51 (BO); ibid., 1 ix 1994, D. Girmansyah 53 (BO); Gunung Rantemario, 27 iv 2009, D. C. Thomas \& W.H. Ardi 0998 (BO, E, L).

The specific epithet is derived from prionotos (Greek - jagged) and refers to both the serrulate wings of the ovaries and fruits and the serrulate tepals of the female flowers (Fig. 6F, G).

Begonia prionota is a very distinct species. Diagnostic characters include the serrulate wings of the fruits, the irregularly serrate tepals of the female flowers, and the unusual architecture of the male superinflorescences, which are characterised by multiple branchings, well-developed internodes and monochasia as partial inflorescences.

Begonia rantemarioensis D.C.Thomas \& Ardi, sp. nov. Sect. Petermannia. Figs 1, 7. Begoniae sanguineopilosae D.C.Thomas \& Ardi similis sed a qua foliis majoribus $(11-15.7 \times 4.5-7.7 \mathrm{~cm}$ nec $5.5-12 \times 2-5 \mathrm{~cm})$, marginibus foliorum profunde duplicoserratis usque vadose lobatis et indumento in ovariis tepalisque rubello carenti differt. - Type: Indonesia, Sulawesi, Sulawesi Selatan, Gunung Rantemario, primary rainforest on steep slope, $03^{\circ} 24^{\prime} 32.3^{\prime \prime} \mathrm{S}, 120^{\circ} 00^{\prime} 24.9^{\prime \prime} \mathrm{E}, 1978 \mathrm{~m}, 24$ iv 2009, D.C. Thomas \& W.H. Ardi 09-82 (holo E; iso BO, L).

Perennial, dioecious? herb, with erect stems, to c.60 cm tall, glabrous except for a sparse indumentum of microscopic, glandular hairs. Stems branched; internodes c.3-16 cm long, brownish-reddish. Leaves alternate; usually with basifixed laminas or sometimes some leaves strongly excentrically peltate; stipules caducous, 11-17 $\times$ $7-10 \mathrm{~mm}$, elliptic to ovate, with an abaxially prominent midrib that projects up to c. $4 \mathrm{~mm}$ at the apex; petioles 3-9 $\mathrm{cm}$ long, brownish-reddish; lamina $11-15.7 \times 4.5$ $7.7 \mathrm{~cm}$, very asymmetric, ovate to elliptic, leaf margin slightly sinuate close to the petiole (strongly excentrically peltate leaves) or base cordate and lobes not overlapping (basifixed laminas), apex acuminate, margin biserrate to shallowly lobed (up to c. $25 \%$ of the lamina width), irregularly scalloped, teeth not bristle-pointed, 

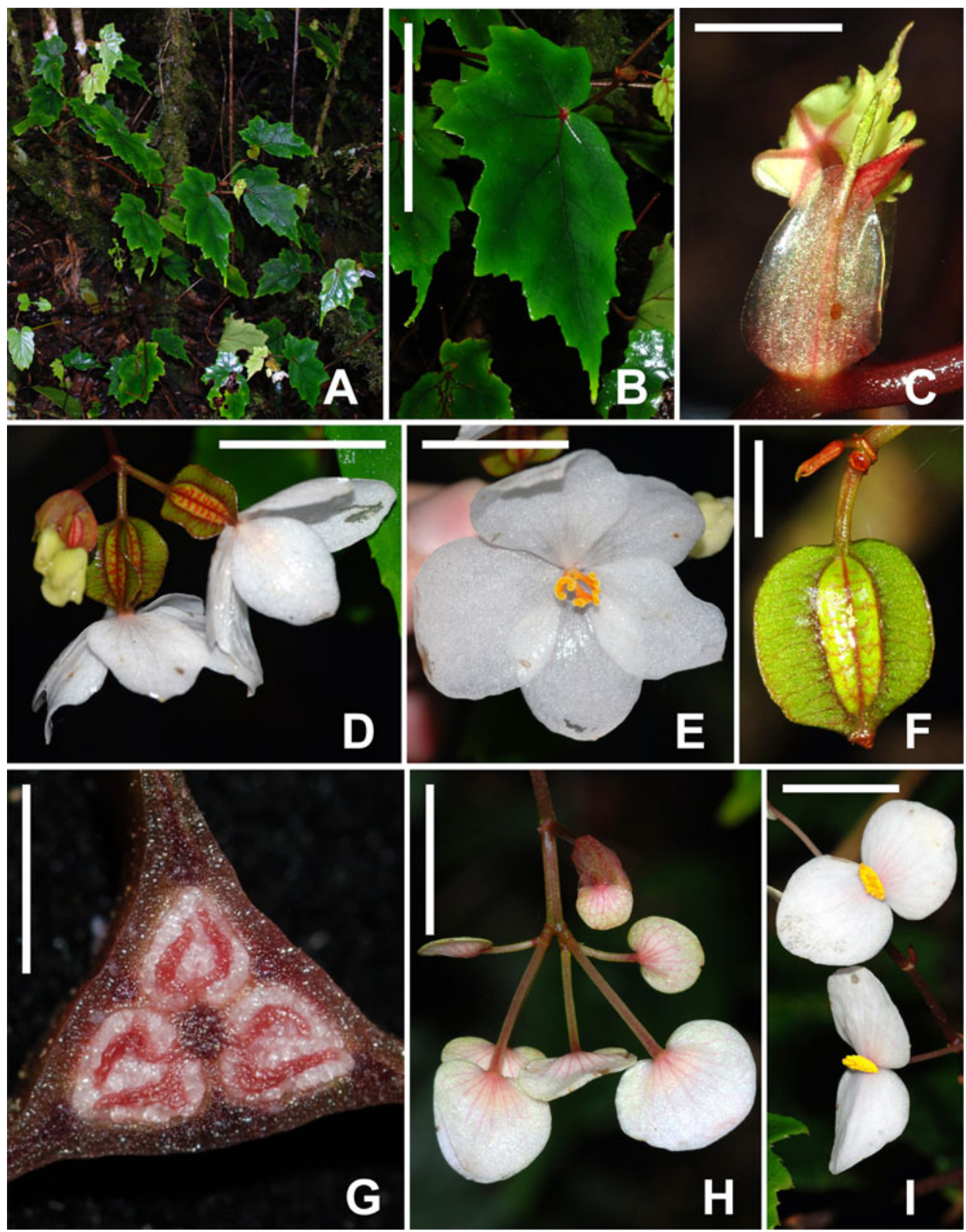

FIG. 7. Begonia rantemarioensis D.C.Thomas \& Ardi. A, habit; B, leaf; C, stipule; D, female inflorescence; E, female flower, front view; F, fruit; G, ovary, cross-section, three-locular with axile, bilamellate placentae; $\mathrm{H}$, cymose-subumbellate male inflorescence; I, male flowers. A-G: D. C. Thomas \& W.H. Ardi 09-78; H, I: D. C. Thomas \& W.H. Ardi 09-82. Scale bars: B $=6 \mathrm{~cm}$; $\mathrm{C}=8 \mathrm{~mm} ; \mathrm{D}, \mathrm{E}, \mathrm{I}=20 \mathrm{~mm} ; \mathrm{F}, \mathrm{H}=16 \mathrm{~mm} ; \mathrm{G}=3 \mathrm{~mm}$. 
adaxial surface dark green and abaxial surface pale green, coriaceous, primary veins 4-5, actinodromous, secondary veins craspedodromous. Inflorescences: female inflorescences 2-flowered, with 1-2 partial inflorescences at subsequent nodes, peduncles c. $1 \mathrm{~mm}$ long; male inflorescences composed of 2-7 cymose-subumbellate partial inflorescences, each with usually 2 compressed monochasia with 1-3 flowers, peduncles 9-14 mm long. Male flowers: pedicels 18-32 mm long; tepals 2, white with pale pinkish veins to pink, $14-20 \times 16-20 \mathrm{~mm}$, broadly ovate to suborbicular, base cordate, apex rounded; androecium of c.48-57 stamens, yellow, filaments up to c. $2.5 \mathrm{~mm}$ long, slightly fused at the base, anthers c. $1-1.5 \mathrm{~mm}$ long, obovate to oblong, dehiscing through unilaterally positioned slits that are $>1 / 2$ as long as the anther. Female flowers: pedicels 6-8 mm long; tepals 5, white, subequal, 21-26 $\times 15$ $20 \mathrm{~mm}$, elliptic to suborbicular; ovary ellipsoid, locules 3, placentation axile, placentae bilamellate, wings 3, triangular or crescent-shaped, subequal, base rounded, apex rounded or truncate, widest at the apex or the middle, style basally shortly fused, 3-branched, each stylodium bifurcate in the stigmatic region, stigmatic surface a spirally twisted papillose band, yellow. Fruiting pedicels up to c. $8 \mathrm{~mm}$ long. Fruits slightly fleshy, ellipsoid, 13-16 $\times 7-8 \mathrm{~mm}$ (excluding the wings), indehiscent?, wing shape as for ovary, 7-8 $\mathrm{mm}$ wide at the widest point (in the middle part or at the apex of the ovary); seeds ellipsoidal, c.0.3-0.4 mm long, collar cells c.1/2-2/3 of the length of the seed.

Distribution. Indonesia, Sulawesi, Sulawesi Selatan, Latimojong Mountains, Gunung Rantemario (Fig. 1).

Habitat. This is a rainforest floor species, growing on steep slopes between c. 1500 and $2000 \mathrm{~m}$ above sea level.

Proposed IUCN conservation category. Least Concern (LC). The distribution of Begonia rantemarioensis lies just outside the western border of the Pegunungan Latimojong Protection Forest (IUCN category VI). Although Begonia rantemarioensis is relatively rare in the area, several subpopulations were observed in habitats located in primary rainforest not yet encroached by human habitation, agriculture or commercial logging activities. Therefore, a 'Least Concern' status seems to be indicated.

Additional specimens examined. SulawesI. South Sulawesi: Subdivision Enrekan, between Angin Angin and Pintealon Forest, 15 vi 1937, P.J. Eyma 478 (L, U); Latimojong Mountains, Gunung Rantemario, 1985, A.J. Whitten s.n. (L); ibid., 5 iii 2000, G. Argent et al. 233 (E); ibid., 28 i 2009, M. Ardiyani et al. 164 (BO, E, SING); ibid., 23 iv 2009, D. C. Thomas \& W.H. Ardi 09-78 (BO, E, L); ibid., 27 iv 2009, D.C. Thomas \& W.H. Ardi 09-94 (BO, E, L); ibid., 27 iv 2009, D.C. Thomas \& W.H. Ardi 09-96 (BO, E, L).

The specific epithet refers to the collection locality of the type material, Gunung Rantemario (Latin, -ensis - originating from).

Dioecy is a rare sexual system in the predominantly monoecious genus Begonia, and in Asian Begonia it has only been reported from a few species placed in Begonia 
section Sphenanthera (Hassk.) Warb. (Tebbitt, 1997; Tebbitt et al., 2006; Gu et al., 2007), one Sulawesi species in Begonia section Petermannia (B. mekonggensis Girm. \& Wiriad; Girmansyah et al., 2009), and the Himalayan B. dioica Buch.-Ham. ex D.Don, which is currently placed in the polyphyletic Begonia section Diploclinium. The determination of dioecy in Begonia can be problematic, as many species show well-developed dichogamy. This can easily result in erroneous descriptions of dioecy in the genus (Badcock, 1998). However, several observations indicate that Begonia rantemarioensis belongs to a group of closely related Sulawesi endemics which exhibit real dioecy. Firstly, the suggestions of dioecy are based on field observations. Several populations of Begonia rantemarioensis were observed in the field and several individuals, often growing closely together, showed various ontogenetic stages of only female or only male flowers, respectively. Secondly, phylogenies based on chloroplast DNA data indicate that Begonia guttapila and another undescribed species (D.C. Thomas \& W.H. Ardi 08-84 [E]) are closely related to B. rantemarioensis (Thomas, 2010). Material of Begonia guttapila and the closely related undescribed species has been cultivated at Bali Botanic Garden for several years, and different individuals consistently develop only male or only female flowers, respectively (Hartutiningsih, pers. comm.). Begonia rantemarioensis is in cultivation at Bali Botanic Garden and further observations will show whether dioecy can be confirmed in this and closely related species. The putative dioecy, the succulent, coriaceous leaves and the semi-fleshy and maybe indehiscent fruits indicate a close relationship to Begonia sanguineopilosa and $B$. torajana, which are described below. Begonia imperfecta Irmsch., B. sarasinorum Irmsch. and B. sphenocarpa Irmsch., which have been described from Central and South Sulawesi, are only known from the unisexual type material, and may belong to this group as well. However, further collections and field observations of these poorly known species are needed to confirm this.

Begonia sanguineopilosa D.C.Thomas \& Ardi, sp. nov. Sect. Petermannia. Figs 1, 8. Begoniae celebicae Irmsch. similis a qua pedicellis florum masculorum longioribus (18-32 mm longis nec c. $15 \mathrm{~mm}$ ), tepalis florum masculorum multo longoribus (18-32 mm longis nec c.9 mm) et tepalis florum femineorum multo longoribus (15-32 mm longis nec c.11-12 mm) differt. - Type: Indonesia, Sulawesi, Sulawesi Barat, Gunung Mambulinin, 02 53'42.5"S, 119²1'37.6"E, 1856 m, 11 v 2009, D.C. Thomas \& W.H. Ardi 09-129 (holo E; iso BO, L).

Perennial, dioecious? herb, with erect stems, to $\mathrm{c} .40 \mathrm{~cm}$ tall, with a sparse indumentum of microscopic, glandular trichomes and multicellular, simple trichomes up to c. $1.2 \mathrm{~mm}$ long on all above-ground vegetative parts. Stems branched; internodes c.2-10.5 cm long, reddish to brownish. Leaves alternate; stipules caducous, $8-15 \times 3-8 \mathrm{~mm}$, ovate, elliptic or oblong, with an abaxially prominent midrib that projects shortly at the apex; petioles 3-6 cm long, reddish; lamina 5.5-12 $\times$ $2-5 \mathrm{~cm}$, basifixed, very asymmetric, ovate, elliptic or oblong, base cordate and lobes not overlapping, apex acuminate, margin biserrate to slightly lobed (up to c. $20 \%$ of 

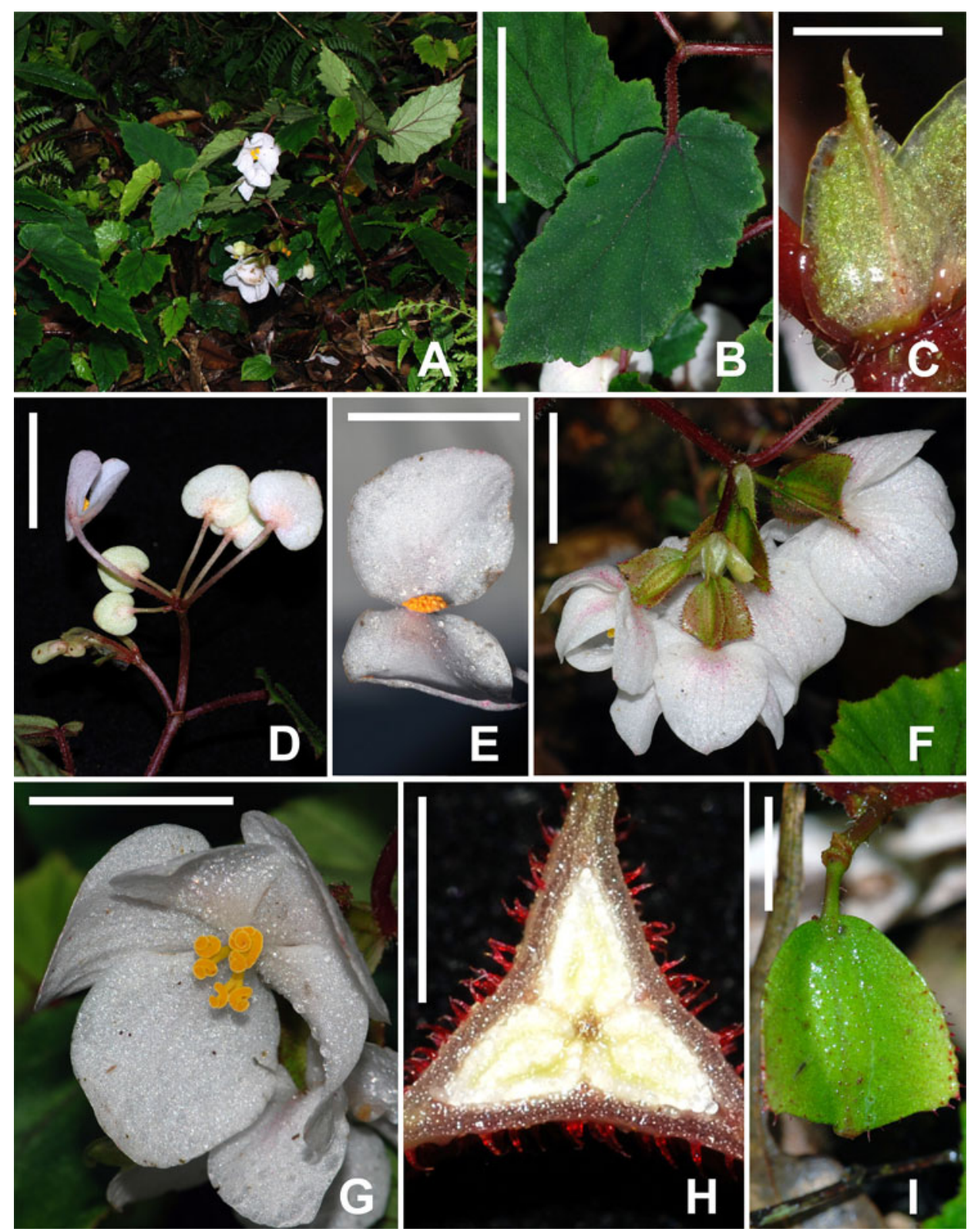

FIG. 8. Begonia sanguineopilosa D.C.Thomas \& Ardi. A, habit; B, leaf; C, stipule; D, male cymose-subumbellate partial inflorescence; E, male flower, front view; F, female inflorescence; $\mathrm{G}$, female flower, front view; $\mathrm{H}$, ovary, cross-section, three-locular with axile, bilamellate placentae; I, fruit. A-C, F-I: D.C. Thomas \& W.H. Ardi 09-129; D, E: D.C. Thomas \& W.H. Ardi 09-128. Scale bars: $\mathrm{B}=4 \mathrm{~cm} ; \mathrm{C}=5 \mathrm{~mm} ; \mathrm{D}=22 \mathrm{~mm} ; \mathrm{E}=18 \mathrm{~mm} ; \mathrm{F}=3 \mathrm{~cm}$; $\mathrm{G}=25 \mathrm{~mm} ; \mathrm{H}=3 \mathrm{~mm} ; \mathrm{I}=10 \mathrm{~mm}$. 
the lamina width), scalloped, teeth not or shortly bristle-pointed, adaxial surface dark green and abaxial surface pale green, primary veins $2-4$, subpinnate, secondary veins craspedodromous. Inflorescences: female inflorescences 2-flowered, with 1-2 partial inflorescences at subsequent nodes, peduncles c. $1 \mathrm{~mm}$ long; male inflorescences composed of 1-3 cymose-subumbellate partial inflorescences, each with 1-3 compressed monochasia with 1-3 flowers, peduncles 5-23 mm long. Male flowers: pedicels c.18-32 mm long; tepals 2, white or whitish tinged with pink, 13-19 $\times 14$ $19 \mathrm{~mm}$, broadly ovate to suborbicular, base cordate, apex rounded, abaxially with a sparse indumentum of multicellular, reddish hairs and microscopic glandular hairs; androecium of c. $32-48$ stamens, yellow, filaments up to c. $2 \mathrm{~mm}$ long, slightly fused at the base, anthers c.1-1.2 mm long, obovate, dehiscing through unilaterally positioned slits that are $>1 / 2$ as long as the anther. Female flowers: pedicels $4-13 \mathrm{~mm}$ long; tepals 5, white or white tinged with pink, subequal, 15-32 $\times 9-29 \mathrm{~mm}$, broadly ovate, elliptic or suborbicular, abaxially with a sparse indumentum of multicellular, reddish hairs and microscopic glandular hairs; ovary ellipsoid, moderately densely hairy, locules 3, placentation axile, placentae bilamellate, wings 3, triangular, subequal, base rounded, apex rounded or truncate, $2-9 \mathrm{~mm}$ at the widest point (at the apex or in the upper third of the ovary), style basally shortly fused, 3-branched, each stylodium bifurcate in the stigmatic region, stigmatic surface a spirally twisted papillose band, yellow. Fruiting pedicels up to c.13 mm long. Fruits semi-fleshy, ellipsoid, c.18 $\times 6 \mathrm{~mm}$ (excluding the wings), moderately hairy to glabrescent, indehiscent?, wing shape as for ovary, up to $10 \mathrm{~mm}$ wide at the widest point; seeds ellipsoidal, c. $0.3 \mathrm{~mm}$ long, collar cells c.1/2-2/3 of the length of the seed.

Distribution. Indonesia, Sulawesi, Sulawesi Barat, Mamasa, Gunung Mambulinin (Fig. 1).

Habitat. This is a rainforest floor species observed on steep slopes between c.1800 and $2100 \mathrm{~m}$ above sea level.

Proposed IUCN conservation category. Vulnerable (VU D2). Large areas of Mamasa valley have been deforested to make way for settlements and the cultivation of rice and other crops. Coffee plantations and logged areas reach up to almost $2000 \mathrm{~m}$ above sea level on the southwestern flank of Gunung Mambulinin. These completely converted areas border the locality of Begonia sanguineopilosa, which is in an area which has no legally protected status. All available Begonia specimens from A, B, BM, BO, CEB, E, K, L, SING and WAG have been consulted, and hence it must be assumed that Begonia sanguineopilosa has a very restricted range. However, further exploration of the largely unexplored and extensive rainforests of the Quarles Mountain Range are needed to confirm whether Begonia sanguineopilosa is a rare local endemic or shows a wider distribution. We adopt a cautionary approach here, as the existing data indicate that Begonia sanguineopilosa is "prone to the effects of human activities or stochastic events within a very short time period in an uncertain future' (IUCN, 2001). 
Additional specimens examined. Sulawesi. West Sulawesi: Mamasa, Gunung Mambulinin, $11 \mathrm{v}$ 2009, D.C. Thomas \& W.H. Ardi 09-125 (BO, E, L); ibid., 11 v 2009, D.C. Thomas \& W.H. Ardi 09-127 (BO, E, L); ibid., 11 v 2009, D.C. Thomas \& W.H. Ardi 09-128 (BO, E, L).

The specific epithet is a compound of sanguineus (Latin - blood-red) and pilosus (Latin - hairy). It refers to the red indumentum of the ovary and the abaxial surfaces of the tepals.

Begonia sanguineopilosa belongs to a group of closely related species which are characterised by putative dioecy, fleshy or semi-fleshy fruits, and succulent, leathery leaves (see notes under Begonia rantemarioensis). Within this group Begonia sanguineopilosa is distinct because of the relatively narrow leaves with a subpinnate venation, the large tepals of the female flowers, as well as the reddish indumentum on the ovary and the abaxial tepal surfaces (see the identification key below).

\section{Begonia torajana D.C.Thomas \& Ardi, sp. nov. Sect. Petermannia. Figs 1, 9.}

Begoniae imperfectae Irmsch. similis a qua staminibus multo magis numerosis (c.52-66 nec c.30) et tepalis florum masculorum multo majoribus $(11-21 \times 14$ $19 \mathrm{~mm}$ nec c. $7 \times 9 \mathrm{~mm})$ differt. - Type: Indonesia, Sulawesi, Sulawesi Selatan, Gunung Sesean, $02^{\circ} 54^{\prime} 08.9^{\prime \prime} \mathrm{S}, 119^{\circ} 52^{\prime} 40.9^{\prime \prime} \mathrm{E}, 1819 \mathrm{~m}, 1 \mathrm{v}$ 2009, D.C. Thomas \& W.H. Ardi 09-106 (holo E; iso BO, L).

Perennial, dioecious? herb, with erect stems, to c. $150 \mathrm{~cm}$ tall, glabrous except for a sparse indumentum of microscopic, glandular hairs. Stems branched; internodes c.4-21.5 cm long, reddish. Leaves alternate; stipules caducous, 10-17 $\times 4-9 \mathrm{~mm}$, ovate to oblong, with an abaxially prominent midrib that projects shortly at the apex; petioles 5.5-20 cm long, reddish; lamina 9.5-19.8 $\times 4.5-12 \mathrm{~cm}$, basifixed, very asymmetric, ovate to elliptic, base cordate, lobes not or sometimes slightly overlapping, apex acuminate, margin biserrate, irregularly scalloped, teeth not bristlepointed, adaxial surface dark green and abaxial surface pale green, coriaceous, primary veins 4-5, actinodromous, secondary veins craspedodromous. Inflorescences: female inflorescences 2-flowered, with 1-2 partial inflorescences at subsequent nodes, peduncles c.2-17 mm long; male inflorescences composed of 1-6 cymosesubumbellate partial inflorescences, each with 3-5 compressed monochasia with 3-5 flowers, peduncles 9-15 mm long. Male flowers: pedicels c.18-20 mm long; tepals 2, whitish with pale pink veins or pinkish, 11-21 $\times 14-19 \mathrm{~mm}$, broadly ovate to suborbicular, base cordate, apex rounded; androecium of c.52-66 stamens, yellow, filaments up to c. $2 \mathrm{~mm}$ long, slightly fused at the base, anthers c.1-1.2 mm long, obovate, dehiscing through unilaterally positioned slits that are $>1 / 2$ as long as the anther. Female flowers: pedicels 6-8 mm long; tepals 5, white, subequal, 18-27 $\times 12$ $15 \mathrm{~mm}$, elliptic, sometimes irregularly serrate at the apex; ovary ellipsoid, locules 3 , placentation axile, placentae bilamellate, wings 3, triangular to crescent-shaped, subequal, base rounded, apex rounded or truncate, widest subapically, style basally shortly fused, 3-branched, each stylodium bifurcate in the stigmatic region, stigmatic surface a spirally twisted papillose band, yellow. Fruiting pedicels up to c.6-9 $\mathrm{mm}$ 

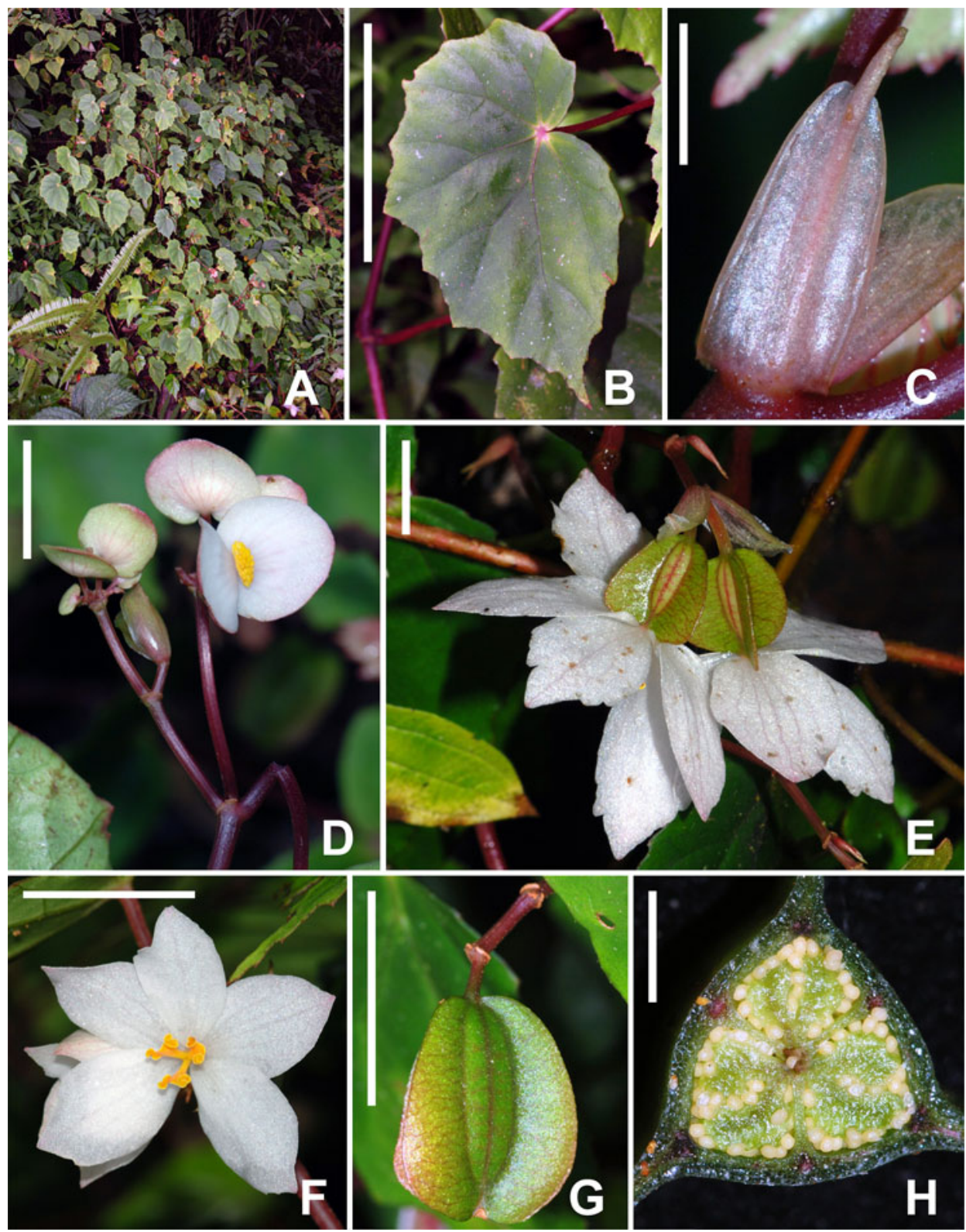

FIG. 9. Begonia torajana D.C.Thomas \& Ardi. A, habit; B, leaf; C, stipule; D, male inflorescence; $\mathrm{E}$, female inflorescence; $\mathrm{F}$, female flower, front view; $\mathrm{G}$, fruit; $\mathrm{H}$, fruit, crosssection, three-locular with axile, bilamellate placentae. A-C, E-H: D.C. Thomas \& W.H. Ardi 09-106; D: D.C. Thomas \& W.H. Ardi 09-105. Scale bars: B = $10 \mathrm{~cm} ; \mathrm{C}=5 \mathrm{~mm}$; D = $16 \mathrm{~mm}$; $\mathrm{E}=10 \mathrm{~mm} ; \mathrm{F}=24 \mathrm{~mm} ; \mathrm{G}=18 \mathrm{~mm} ; \mathrm{H}=3 \mathrm{~mm}$. 
long. Fruits slightly fleshy, ellipsoid, 15-20 $\times$ 5-7 $\mathrm{mm}$ (excluding the wings), indehiscent?, wing shape as for ovary, $8-10 \mathrm{~mm}$ wide at the widest point (in the middle part or at the apex of the ovary); seeds ellipsoidal, c.0.3-0.4 mm long, collar cells c.1/2-2/3 of the length of the seed.

Distribution. Indonesia, Sulawesi, Sulawesi Selatan, Tanah Toraja, Gunung Sesean and the area between Palopo and Rantepao (Fig. 1).

Habitat. This is a rainforest floor species, growing on steep slopes between c.800 and $2000 \mathrm{~m}$ above sea level. Although this species grows best in full shade and moist conditions, it has a certain tolerance towards higher light intensities and can be found in disturbed habitats at roadsides dominated by Gleicheniaceae species.

Proposed IUCN conservation category. Least Concern (LC). All of the observed subpopulations were in areas which have no legal protection. The subpopulations on Gunung Sesean, where Begonia torajana is locally common, were restricted to pockets of primary forest surrounded by strongly disturbed habitats including large areas which were fire-cleared for cattle grazing. The subpopulations along the road from Rantepao to Palopo may ultimately fare better since they are in areas of extensive rainforest protected by mountainous terrain. The inaccessibility of the primary rainforests of the Rantepao-Palopo divide offers some natural protection.

Additional specimens examined. SulawesI. South Sulawesi: Tana Toraja, Gunung Sesean, 24 viii 1993, J.J. Wieringa 1889 (L, WAG); ibid., 1 v 2009, D. C. Thomas \& W.H. Ardi 09-104 (BO, E, L); ibid., 1 v 2009, D.C. Thomas \& W.H. Ardi 09-105 (BO, E, L); Tanah Toraja, Rantepao-Palopo divide, 2 ii 2004, J.J. Vermeulen 2411 (SING); ibid., 30 iv 2009, D.C. Thomas \& W.H. Ardi 09-102 (BO, E, L).

The specific epithet refers to the ethnic group of the Toraja and their traditional territory (Tanah Toraja in South Sulawesi), which covers the known distribution of Begonia torajana.

Begonia torajana belongs to a group of closely related species which are characterised by putative dioecy, fleshy or semi-fleshy fruits, and succulent, leathery leaves (see notes under Begonia rantemarioensis). With regards to the leaf morphology and male inflorescence architecture it is similar to Begonia imperfecta, which is only known from the male type material. However, the tepals of the male flowers are much larger in Begonia torajana $(11-21 \times 14-19 \mathrm{~mm})$ than in B. imperfecta $($ c. $7 \times 9 \mathrm{~mm}$ ), and the androecium in B. torajana consists of c.52-66 stamens, while only c.30 stamens have been reported in Begonia imperfecta (Irmscher, 1914).

Begonia vermeulenii D.C.Thomas, sp. nov. Sect. Petermannia. Figs 1, 10.

$\mathrm{Ab}$ aliis speciebus sectionis Petermanniae combinatione characterum foliorum peltatorum et fructibus longis (usque ad $48 \mathrm{~mm}$ ), fusiformibus, exalatis, carnosis differt. - Type: Indonesia, Sulawesi, Sulawesi Selatan, Buntu area, Kampong 

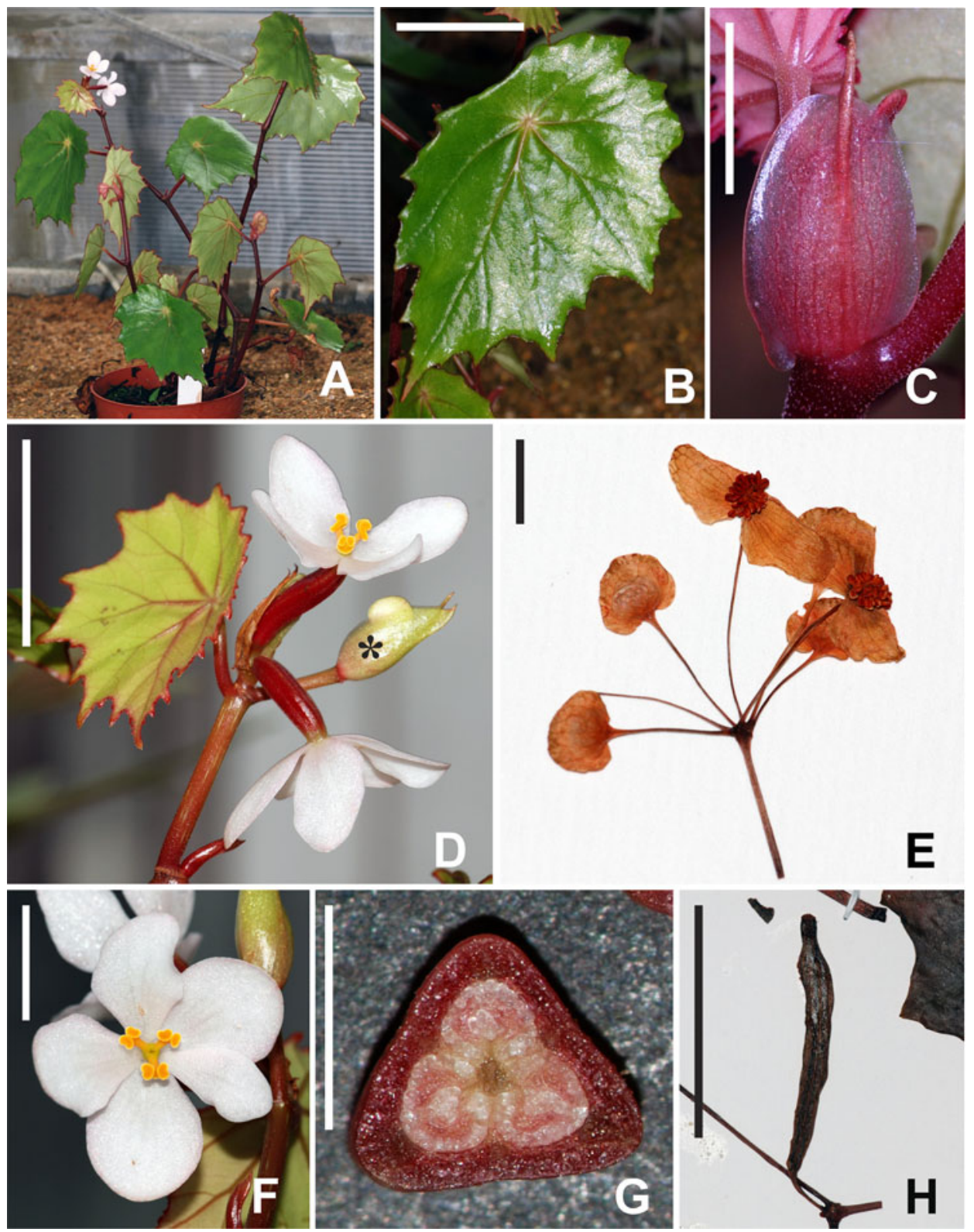

FIG. 10. Begonia vermeulenii D.C.Thomas. A, habit; B, leaf; C, stipule; D, inflorescence, the asterisk indicates a developing male inflorescence; E, male cymose-subumbellate partial inflorescence; F, female flower, front view; G, ovary, cross-section, three-locular with axile, bilamellate placentae; H, fruit. A-D, F-G: D.C. Thomas 08-167; E, H: J.J. Vermeulen 2301. Scale bars: $\mathrm{B}=4 \mathrm{~cm} ; \mathrm{C}=8 \mathrm{~mm} ; \mathrm{D}=3 \mathrm{~cm} ; \mathrm{E}, \mathrm{F}=9 \mathrm{~mm} ; \mathrm{G}=3 \mathrm{~mm} ; \mathrm{H}=5 \mathrm{~cm}$. 
Lokkok, $03^{\circ} 13^{\prime} \mathrm{S}, 119^{\circ} 48^{\prime} \mathrm{E}, 1500-1700 \mathrm{~m}, 15$ ix 2003, J.J. Vermeulen 2301 (holo WAG; iso SING).

Perennial, monoecious herb, with erect stems, to c.100 cm tall, glabrous except for a sparse indumentum of microscopic, glandular hairs. Stems branched; internodes c.2-12 cm long, reddish. Leaves alternate; peltate; stipules caducous, 8-21 $\times 5-9 \mathrm{~mm}$, ovate to oblong, with an abaxially prominent midrib that projects shortly at the apex; petioles 3.5-9.5 cm long, reddish or greenish; lamina $8-15.5 \times 5.5-9.5 \mathrm{~cm}$, very asymmetric, ovate to elliptic, apex acuminate, margin biserrate, irregularly scalloped, teeth not bristle-pointed, adaxial surface dark green and abaxial surface pale green, coriaceous, primary veins 5-6, actinodromous, secondary veins craspedodromous. Inflorescences: protogynous; female inflorescences 2-flowered, usually positioned one node below the male inflorescences, peduncles c. $1 \mathrm{~mm}$ long; male inflorescences composed of 1-3 cymose-subumbellate partial inflorescences, each with 2 compressed monochasia with up to 5 flowers, peduncles up to $16 \mathrm{~mm}$ long. Male flowers: pedicels c.10-19 $\mathrm{mm}$ long; tepals 2 , white, 5-8 $\times$ 8-10 $\mathrm{mm}$, broadly ovate to suborbicular, base cordate, apex rounded; androecium of c.35-44 stamens, yellow, filaments up to c. $1.4 \mathrm{~mm}$ long, slightly fused at the base, anthers c. $1.2 \mathrm{~mm}$ long, obovate, dehiscing through unilaterally positioned slits that are c.1/2 as long as the anther. Female flowers: pedicels c.5-10 mm long; tepals 5, white or white tinged with pink, subequal to unequal, $15-17 \times 6-11 \mathrm{~mm}$, obovate to elliptic; ovary ellipsoid, wingless, locules 3 , placentation axile, placentae bilamellate, style basally shortly fused, 3-branched, each stylodium bifurcate in the stigmatic region, stigmatic surface a spirally twisted papillose band, yellow. Fruiting pedicels up to c. $1 \mathrm{~cm}$ long. Fruits fleshy, ellipsoid, c.44-48 $\times 5-6 \mathrm{~mm}$, indehiscent; seeds ellipsoidal, c. $0.3 \mathrm{~mm}$ long, collar cells c.1/2-2/3 of the length of the seed.

Distribution. Indonesia, Sulawesi, Sulawesi Selatan, Buntu area, Kampong Lokkok (Fig. 1).

Habitat. This is a rainforest floor species, growing on limestone slopes between c.1500 and $1700 \mathrm{~m}$ above sea level.

Proposed IUCN conservation category. Vulnerable (VU D2). The known distribution of Begonia vermeulenii falls outside any legally protected area. Furthermore, extensive areas close to the collection site are at best highly degraded or entirely lacking in native vegetation since they have been converted into rice fields and human settlements. Remnant primary forests in the area are often restricted to inaccessible limestone slopes. Although all available Begonia specimens from A, B, BM, BO, CEB, E, K, L, SING and WAG have been consulted, only one collection is known. Other subpopulations could not be detected in an exploration of the area close to the collection site. Hence it must be assumed, at least until more intensive collecting on Sulawesi reveals otherwise, that this species has a very restricted extent of occurrence. Therefore, it is likely that the population is 'prone to the effects of human activities or stochastic events within a very short time period in an uncertain future' (IUCN, 2001). 
This species is named in honour of the Dutch botanist and orchid specialist Jaap J. Vermeulen. Begonia vermeulenii is one of the most distinct Sulawesi Begonia species because of the conspicuously long, fleshy, wingless fruits and the succulent, peltate leaves. The fleshy fruits, the subumbellate male inflorescences and the succulent leaves indicate a close relationship with other South Sulawesi species including Begonia comestibilis, B. guttapila, B. rantemarioensis, B. sanguineopilosa and B. torajana.

\section{Identification key to Begonia in South and West Sulawesi}

1a. Leaves palmately compound 2

1b. Leaves simple, sometimes lobed 3

2a. Small, delicate plants, to c.40 cm in height; glabrous except for microscopic glandular hairs; female flowers solitary; pedicels of the fruits very short (c.1 mm); wings of the fruits subequal B. rachmatii

2b. Robust plants up to $\mathrm{c} .100 \mathrm{~cm}$ in height; moderately to densely hairy on all above-ground vegetative parts; female inflorescence 2-flowered; pedicel of the fruits long (16-19 mm); wings of the fruits unequal with one wing much larger than the other two

B. insueta

3a. Leaves peltate (although a few leaves, especially the subtending leaves of the inflorescences, sometimes with basifixed laminas)

3b. Leaf laminas basifixed 4

4a. Ovaries and fruits wingless, fruits $>4 \mathrm{~cm}$ long; tepals of male flowers up to c. $10 \mathrm{~mm}$ broad, androecium of fewer than 50 stamens B. vermeulenii

4b. Ovaries and fruits with well-developed wings, fruits $<3 \mathrm{~cm}$ long; tepals of male flowers 11-17 mm broad, androecium of more than 60 stamens _ B. comestibilis

5a. Female inflorescences 1- or 2-flowered and clearly spatially separated from the male inflorescences or inflorescence parts; fruits dehiscent or fleshy, with welldeveloped wings

5b. Female and male flowers occurring together in cymose inflorescences; fruits fleshy with strongly reduced wings 24

6a. Plants with swollen underground organs consisting of one to several tuberous units up to $3.1 \mathrm{~cm}$ long and $1.1 \mathrm{~cm}$ thick; filaments of the stamens fused into a short filament column; acaulescent or with short aerial stem $<30 \mathrm{~cm}$ in height B. siccacaudata J.Door.

6b. Plants without specialised swollen underground organs; filaments free or only fused at the very base; plants usually $>30 \mathrm{~cm}$ in height, if smaller then still with well-developed aerial stems 
7a. Petioles with a sparse to dense indumentum of multicellular, simple trichomes and interspersed multicellular, branched trichomes

B. ozotothrix D.C.Thomas ${ }^{1}$

7b. Petioles glabrous or hairy, but never with branched trichomes 8

8a. Leaf margin distantly dentate and unevenly repand

B. sarasinorum

8 b. Leaf margin serrate to biserrate or dentate to bidentate, sometimes shallowly lobed (up to c. $25 \%$ of the lamina width) 9

9a. Male inflorescences dichasial (sometimes with monochasial branching in the apical part), inflorescence internodes short, but well developed; peduncles of female inflorescences $>2.5 \mathrm{~cm}$ long 10

9b. Male inflorescences monochasial, internodes often strongly compressed, but sometimes axes shortly developed; peduncles of female inflorescences $<2.5 \mathrm{~cm}$ long 11

10a. Leaf margin biserrate to shallowly lobed; male flowers with (2-3-)4 tepals usually $>20 \mathrm{~mm}$ wide B. grandipetala Irmsch.

10b. Leaf margin finely serrate or dentate to bidentate or biserrate; male flowers with 2 tepals up to $18 \mathrm{~mm}$ wide B. bonthainensis Hemsl.

11a. Male cymose inflorescences with 2(-3) flowers; leaf laminas $<7 \mathrm{~cm}$ long B. didyma D.C.Thomas \& Ardi

11b. Male cymose inflorescences with more than 3 flowers; larger leaves $>7 \mathrm{~cm}$ long 12

12a. Peduncle of compressed, cymose male inflorescences $<5 \mathrm{~mm}$ long 13

12b. Peduncles of cymose male inflorescences $>5 \mathrm{~mm}$ long 14

13a. Petioles $2.5-8 \mathrm{~cm}$ long; tepals of male flowers $10-12 \times 10-12 \mathrm{~mm}$ B. aff. mekonggensis Girm. \& Wiriad. ${ }^{2}$

13b. Petioles 7-15 cm long; tepals of male flowers $11-27 \times 18-28 \mathrm{~mm}$ B. sp. $\mathrm{I}^{3}$

${ }^{1}$ Begonia ozotothrix has been described from Central Sulawesi (Thomas et al., 2009a) and has not been reported from South Sulawesi before. However, this species has recently been collected in the Karaenta Reserve close to the Bantimurung National Park in South Sulawesi (D.C. Thomas \& W.H. Ardi 09-76 [BO, E, L]; see also S. Soenarko 304 [BO], C. G. G.J. van Steenis 10443 [BO], W. Meijer 10965 [BO, L]). Collections from this southern subpopulation exhibit the species' characteristic branched hairs and differ from the collections made in Central Sulawesi only in the denser indumentum and slightly less compressed male inflorescences.

${ }^{2}$ Begonia mekonggensis is a local endemic from Southeast Sulawesi (Sulawesi Tenggara) (Girmansyah et al., 2009). Vegetatively and generatively similar material has recently been collected in the rainforests of the Mangkutana-Pendolo divide close to the Feruhumpenai Nature Reserve (D.C. Thomas \& W.H. Ardi 09-108, 09-111 [BO, E]).

${ }^{3}$ This species will be described in a forthcoming edition of Reinwardtia (Harry Wiriadinata, pers. comm.). Begonia sp. I is distinct by the very large greenish-white or white tepals of the male flowers (up to c. $27 \times$ $28 \mathrm{~mm}$ ) and the subsessile cymose-subumbellate male inflorescences; see P. Harwood 126 (BKL), W.S. Hoover et al. 889 (BO), M. Tebbitt s.n. (E), D.C. Thomas \& W.H. Ardi 08-82 (E), and the illustration in Tebbitt (2005a: 100). 
14a. Ovaries and fruits with multicellular trichomes each with a conspicuously broad, bulbous base narrowing into a fine extended tip B. guttapila

14b. Ovaries and fruits glabrous or when with multicellular trichomes, then trichomes without conspicuously broad bulbous base 15

15a. Vegetative organs glabrous except for a sparse indumentum of microscopic glandular hairs 16

15b. Above-ground vegetative organs with a sparse to dense indumentum of macroscopically visible multicellular simple trichomes

16a. Number of stamens $<40$ B. imperfecta

16b. Number of stamens $>40$ 17

17a. Small erect herbs $<30 \mathrm{~cm}$ in height; tepals of female flowers $<14 \mathrm{~mm}$ long B. nobmanniae

17b. Tall erect herbs or soft-wooded shrubs $>40 \mathrm{~cm}$ in height; tepals of female flowers $18-27 \mathrm{~mm}$ long 18

18a. Compressed subumbellate male partial inflorescences with $>8$ flowers, composed of 3-5 compressed monochasia, each with 3-5 flowers; tepals of the female flowers often irregularly serrate at the apex; leaf lamina margin biserrate B. torajana

18b. Compressed subumbellate male partial inflorescences with $<8$ flowers, composed of 2 compressed monochasia, each with 1-3 flowers; tepals of the female flowers with entire margins; leaf lamina margin biserrate to shallowly lobed (up to c. $25 \%$ of the lamina width) B. rantemarioensis

19a. Margins of the tepals of the female flowers irregularly serrate at apices B. prionota

19b. Margins of the tepals of the female flowers entire 20

20a. Tepals of female flowers 15-32 mm long; leaf lamina $<5 \mathrm{~cm}$ in width B. sanguineopilosa

20b. Tepals of female flowers $<15 \mathrm{~mm} \mathrm{long,} \mathrm{or} \mathrm{when} \mathrm{slightly} \mathrm{longer} \mathrm{(} B$. sphenocarpa) then leaves $>5 \mathrm{~cm}$ in width 21

21a. Petioles glabrous or very sparsely hairy with macroscopically visible multicellular hairs; teeth of the leaf lamina not extended into fine bristles B. nobmanniae

21b. Petioles densely hairy with macroscopically visible multicellular hairs; teeth of the leaf lamina extended into fine bristles 22

22a. Ovary wings not hairy at the margins; leaves $5-8 \times 3-4.5 \mathrm{~cm}$ B. celebica Irmsch.

22b. Ovary wings hairy at the margins; leaves $7-21.5 \times 5-12.5 \mathrm{~cm}$ 23

23a. Leaf margin serrate; fruits $<15 \mathrm{~mm}$ long; tepals of female flowers 10-12 mm long B. lasioura 
23b. Leaf margin biserrate; fruits $>18 \mathrm{~mm}$ long; tepals of female flowers $12-17 \mathrm{~mm}$ long B. sphenocarpa

24a. Leaves oblong-lanceolate B. aptera

24b. Leaves broadly ovate 25

25a. Plant glabrous

B. rieckei complex

25b. Plant hairy B. robusta Blume complex

\section{ACKNOWLEDGEMENTS}

We are grateful to Dr Eko Baroto Walujo (LIPI, Cibinong Science Centre, BO), Mr Mustaid Siregar and Miss Hartutiningsih (LIPI, Bogor Botanic Gardens) for their support of our expeditions to Sulawesi; to the horticulture staff at Bali Botanic Garden, Bogor Botanic Gardens, the Royal Botanic Garden Edinburgh and the Royal Botanic Gardens Glasgow for their expert care of the Begonia collections; to the curators of A, B, BM, BO, CEB, E, K, L, SING and WAG for allowing us access to herbarium material and living collections; to Dr Mark Tebbitt for sending plant material from Brooklyn Botanic Gardens; and to Dr Robert Mill for the Latin diagnoses. This research would not have been possible without the support of the Indonesian Ministry of Research and Technology (RISTEK) and Direktorat Jenderal Perlindungan Hutan dan Konservasi (DITJET PHKA). The funding of the first author's PhD project by the M. L. MacIntyre Trust, and the support of two expeditions in 2008 and 2009 to Sulawesi by the Royal Horticultural Society, the Stanley Smith (UK) Horticultural Trust and the Systematics Association, is gratefully acknowledged.

\section{REFERENCES}

B ADсоск, Z. (1998). A phylogenetic investigation of Begonia L. section Knesebeckia (Klotzsch) A.DC. PhD thesis, University of Glasgow.

Cannon, C. H., Summers, M., Harting, J. R. \& Kessgler, P. J. A. (2007).

Developing conservation priorities based on forest type, condition, and threats in a poorly known ecoregion: Sulawesi, Indonesia. Biotropica 39(6): 747-759.

Doorenbos, J. M., Sosef, S. M. \& De Wilde, J. J. F. E. (1998). The sections of Begonia including descriptions, keys and species lists. Studies in Begoniaceae VI.

Wageningen Agricultural University Papers 98(2). Wageningen: Wageningen Agricultural University.

Girmansyah, D., Wiriadinata, H., Thomas, D. C. \& Hoover, W. S. (2009). Two new species and one new subspecies of Begonia (Begoniaceae) from Southeast Sulawesi, Sulawesi, Indonesia. Reinwardtia 13(1): 69-74.

Gu, C. Z., Peng, C. I. \& Turland, N. J. (2007). Begoniaceae. In: Wu, Z. Y., Raven, P. H. \& Hong, D. Y. (eds) Flora of China, pp. 153-207. Beijing: Science Press.

Hughes, M. (2008). An Annotated Checklist of Southeast Asian Begonia. Edinburgh: Royal Botanic Garden Edinburgh. 
Hughes, M. \& Pullan, M. (2007). Southeast Asian Begonia Database. Electronic publication accessible via www.rbge.org.uk.

Irmscher, E. (1914). Neue Begoniaceen Papuasiens mit Einschluß von Celebes. Bot. Jahrb. Syst. 50: 335-383.

IUCN (2001). IUCN Red List Categories and Criteria, Version 3.1. IUCN Species Survival Commission. Gland, Switzerland and Cambridge, UK: IUCN.

Теввітт, M. C. (1997). A systematic investigation of Begonia section Sphenanthera (Hassk.) Benth. \& Hook.f. PhD thesis, University of Glasgow.

Tеввітт, M. C. (2005a). Begonias: Cultivation, Identification, and Natural History. Portland, OR: Timber Press.

Теввітт, M. C. (2005b). Three new species and a new subspecies of Begonia (Begoniaceae) from Asia. Edinburgh J. Bot. 61(2-3): 97-107.

Tebittt, M. C., Lowe-Forrest, L., Santoriello, A., Clement, W. L. \& Swensen, S. M. (2006). Phylogenetic relationships of Asian Begonia, with an emphasis on the evolution of rain-ballist and animal dispersal mechanisms in sections Platycentrum, Sphenanthera and Leprosae. Syst. Bot. 31(2): 327-336.

Тном As, D. C. (2010). Phylogenetics and historical biogeography of Southeast Asian Begonia L. (Begoniaceae). PhD thesis, University of Glasgow.

Thomas, D. C. \& Hughes, M. (2008). Begonia varipeltata (Begoniaceae): a new peltate species from Sulawesi, Indonesia. Edinburgh J. Bot. 65(3): 369-374.

Thomas, D. C., Ardi, W. H., Hartutiningsin \& Hughes, M. (2009a). Two new species of Begonia (Begoniaceae) from South Sulawesi, Indonesia. Edinburgh J. Bot. 66(2): 229-238.

Thomas, D. C., Ardi, W. H. \& Hughes, M. (2009b). Two new species of Begonia (Begoniaceae) from Central Sulawesi, Indonesia. Edinburgh J. Bot. 66(1): 103-114. 